\title{
Deformation and Fault Propagation at the Lateral Termination of a Subduction Zone: The Alfeo Fault System in the Calabrian Arc, Southern Italy
}

\author{
Francesco Emanuele Maesano*, Mara Monica Tiberti and Roberto Basili \\ Istituto Nazionale di Geofisica e Vulcanologia, Rome, Italy
}

The Calabrian Arc subduction, southern Italy, is a critical structural element in the geodynamic evolution of the central Mediterranean basin. It is a narrow, northwestdipping slab bordered to the southwest by the Alfeo Fault System (AFS) and to the northeast by a gradual transition to a collision. We used a dense set of two-dimensional high-penetration (up to $12 \mathrm{~s}$ ) multichannel seismic reflection profiles to build a threedimensional model that spans the AFS for over $180 \mathrm{~km}$ of its length. We find that the AFS is made up of four deep-seated major blind segments that cut through the

OPEN ACCESS

Edited by:

Ramon Arrowsmith,

Arizona State University, United States

Reviewed by:

Luigi Jovane,

University of São Paulo, Brazil Jian-Cheng Lee,

Academia Sinica, Taiwan

*Correspondence: Francesco Emanuele Maesano francesco.maesano@ingv.it

Specialty section

This article was submitted to Structural Geology and Tectonics, a section of the journal

Frontiers in Earth Science

Received: 09 January 2020 Accepted: 24 March 2020 Published: 17 April 2020

Citation:

Maesano FE, Tiberti MM and Basili R (2020) Deformation and Fault Propagation at the Lateral Termination of a Subduction Zone: The Alfeo Fault System in the Calabrian Arc, Southern Italy. Front. Earth Sci. 8:107. doi: 10.3389/feart.2020.00107 lower plate, offset the subduction interface, and only partially propagate upward across the accretionary wedge in the upper plate. These faults evolve with a scissor-like mechanism (mode III of rupture propagation). The shallow part of the accretionary wedge is affected by secondary deformation features well aligned with the AFS at depth but also mechanically decoupled from it. Despite the decoupling, the syn-tectonic Pliocene-Holocene deposits that fill in the accommodation space generated by the AFS activity at depth, constrain the age of inception of the AFS and allows us to estimate its throw and propagation rates. The maximum throw value is $6,000 \mathrm{~m}$ in the NW sector and decreases to the SE. Considering the age of faulting, the fault throw rate decreases accordingly from $2.31 \mathrm{~mm} / \mathrm{yr}$ to $1 \mathrm{~mm} / \mathrm{yr}$. The propagation rate decreases from $62 \mathrm{~mm} / \mathrm{yr}$ to $15 \mathrm{~mm} / \mathrm{yr}$ during the Pliocene-Pleistocene, suggesting that also the Calabrian subduction process should have slowed down accordingly. The detailed spatial and temporal reconstruction of this type of faults can reveal necessary information about the evolution of subduction systems.

Keywords: tear fault, fault propagation, decoupling, subduction, Calabrian Arc, Italy

\section{HIGHLIGHTS}

- A scissor-like mechanism characterizes the tear fault at the edge of subducting slabs.

- The Calabrian Arc, Italy, terminates to the south-west on the Alfeo Fault System.

- The Alfeo Fault System is made up by 4 major deep-seated subvertical fault segments.

- The deep-seated faults are decoupled from the brittle features on the seafloor.

- Propagation and slip rates of the tear fault decrease toward the subduction front. 


\section{INTRODUCTION}

Subduction zones stretch across the globe for a length of over $55,000 \mathrm{~km}$. The number of these zones varies in different worldwide compilations (cf. 40 vs. 27 in these two examples: Christophersen et al., 2015; Hayes et al., 2018) depending on the criteria used to identify and report their lateral terminations. Any subduction zone can be hundreds to thousands kilometer long, and the subduction process laterally comes to a change or a halt where the properties of the involved plates change. There, a tearing of the slab forms permitting or facilitating the continuation of the subduction process only on one side. The tearing can propagate upward across the subducting plate and cause deformation in the overriding plate. This peculiar kind of structures has long been referred to as "wrench fault" or "platefree boundary” (e.g., Royden et al., 1987; Knott and Turco, 1991), and it is often associated with transform zones (e.g., Scordilis et al., 1985). Bilich et al. (2001) called them "subduction to strike-slip transitions," whereas Govers and Wortel (2005), after an extensive review, proposed the use of Subduction-Transform Edge Propagators (STEP). According to all these definitions, these shear zones form and tend to remain stable where the subduction process requires tearing of the lithosphere. Although STEPs are not rare (there are at least 14 different STEPs in the world), they are nevertheless quite enigmatic objects. They tend to mimic transform zones, but most of them do not show evidence of strike-slip seismicity (Bilich et al., 2001). The geologically recorded deformation due to STEPs is also expected to vary over time according to the propagation through the plate, possibly because of their peculiar genesis (Govers and Wortel, 2005).

Recently, Gutscher et al. (2019) referred to the acronym STEP as Subduction Tear Edge Propagator, where the letter T stands for "Tear" instead of "Transform." The term tear seems more appropriate than the term transform because it includes not only strike-slip kinematics but also scissor-like movements (mode III of fracture propagation), which is likely the most common type of slab edges (Govers and Wortel, 2005).

Understanding STEPs in the Mediterranean region is of topical interest for the presence of a land-locked system of three subduction zones (Calabrian Arc, Hellenic Arc, and Cyprus Arc), interrupted by continental collision and back-arc opening. STEP-like shear zones, such as the Cephalonia and the PlinyStrabo shear zones for the Hellenic Arc, and the Paphos Fault for the Cyprus Arc (Sachpazi et al., 2000; Govers and Wortel, 2005; Wdowinski et al., 2006; Özbakır et al., 2013; Hall et al., 2014; van Hinsbergen et al., 2014), play a crucial role in controlling the arrangement of this varied structural setting within a relatively small region.

Here we focus on the Calabrian Arc (Figure 1), a very narrow $(\sim 150 \mathrm{~km})$ subduction zone in the central Mediterranean, controlled by slab rollback that started in the late Miocene (8$10 \mathrm{Ma})$ (Goes et al., 2004; Faccenna, 2005) due to the sinking of the Ionian Mesozoic oceanic crust. Due to its tightly curved shape and NW-SE convergence, lithosphere tearing seems to be unavoidable at both edges of the arc. The convergence rate across the Calabrian Arc is in the range of 2-5 mm/yr (Devoti et al., 2008; Carafa et al., 2015). The seismicity is characterized by numerous intraslab earthquakes below $40 \mathrm{~km}$, whereas the shallow seismicity recorded in the last c. 15 years in the Ionian Sea region is very limited and sparse (Figures 1B,D). The largest historical earthquakes in the area (Rovida et al., 2019), such as the south-eastern Sicily, Mw 7.3, earthquake of 1693 and the Central Calabria, Mw 7.0, earthquake of 1905, have been tentatively associated with various geological structures including the shallow portion of the slab interface or with the slab itself. In particular, the south-eastern Sicily, Mw 7.3, earthquake and tsunami of 1693, were also associated to several different causative sources at the western edge of the Calabrian Arc (see Basili et al., 2013 for a summary).

The identification and characterization of lateral terminations of the slab was mainly based on tomography data and on the geologic and geodetic evidence of active tectonics, along with a rather abrupt lateral termination of intraslab seismicity (Guarnieri, 2006; Del Ben et al., 2008; Orecchio et al., 2014, 2015; Barreca et al., 2016; Chiarabba and Palano, 2017; Cultrera et al., 2017; Maesano et al., 2017; Milia et al., 2017; Palano et al., 2017; Carafa et al., 2018).

As recently summarized by Gutscher et al. (2017) (see their Figure 6), three different interpretations exist in the literature regarding the southwestern lateral termination of the Calabrian subduction zone. The first and oldest, maintaining that the slab tear is located along the Malta Escarpment, the second favoring the Alfeo Fault System (the main subject of this work), and the third and most recent, proposing the Ionian Fault (see Figure 1C to locating these three features).

At crustal level, the first hints for the presence of a major fault in the Ionian offshore, cutting through both the Moho and the accretionary wedge, came from the interpretation of the Etnaseis seismic lines by Nicolich et al. (2000) in the near offshore of Mt. Etna. Del Ben et al. (2008) also identified a major fault in a seismic profile farther offshore and considered it to be the southward prolongation of the Tindari-Taormina fault lineament which runs onshore across northeastern Sicily (Figure 1C) and which offshore continuation in the Ionian Sea has been recently documented (Barreca et al., 2019). To the south, Polonia et al. (2011) showed a major shear zone with faults producing a vertical offset that affects the entire accretionary wedge. According to Polonia et al. (2011) and Gallais et al. (2013), this major shear zone can be considered as a STEP fault sensu Govers and Wortel (2005). Gallais et al. (2013) also provided a very accurate map of these shear zone, based on the same seismic profiles considered in previous works, and describe it as the southwestern boundary of the Calabrian Arc subduction zone produced by the retreat of the slab. Gutscher et al. (2016) then produced a detailed reconstruction of the fault traces on the seafloor based on bathymetry and high-resolution shallow seismic data and named this shear zone as Alfeo Fault System. Polonia et al. (2016) estimated the inception of the Alfeo Fault System activity to have occurred in the Middle Pleistocene but contend that the role of the STEP fault has to be assigned to the Ionian Fault which is located c. $20-30 \mathrm{~km}$ to the northeast. Maesano et al. (2017) mapped the deep part of the Alfeo Fault System based on the interpretation of several seismic reflection profiles and highlighted its role in offsetting the Calabrian Arc 


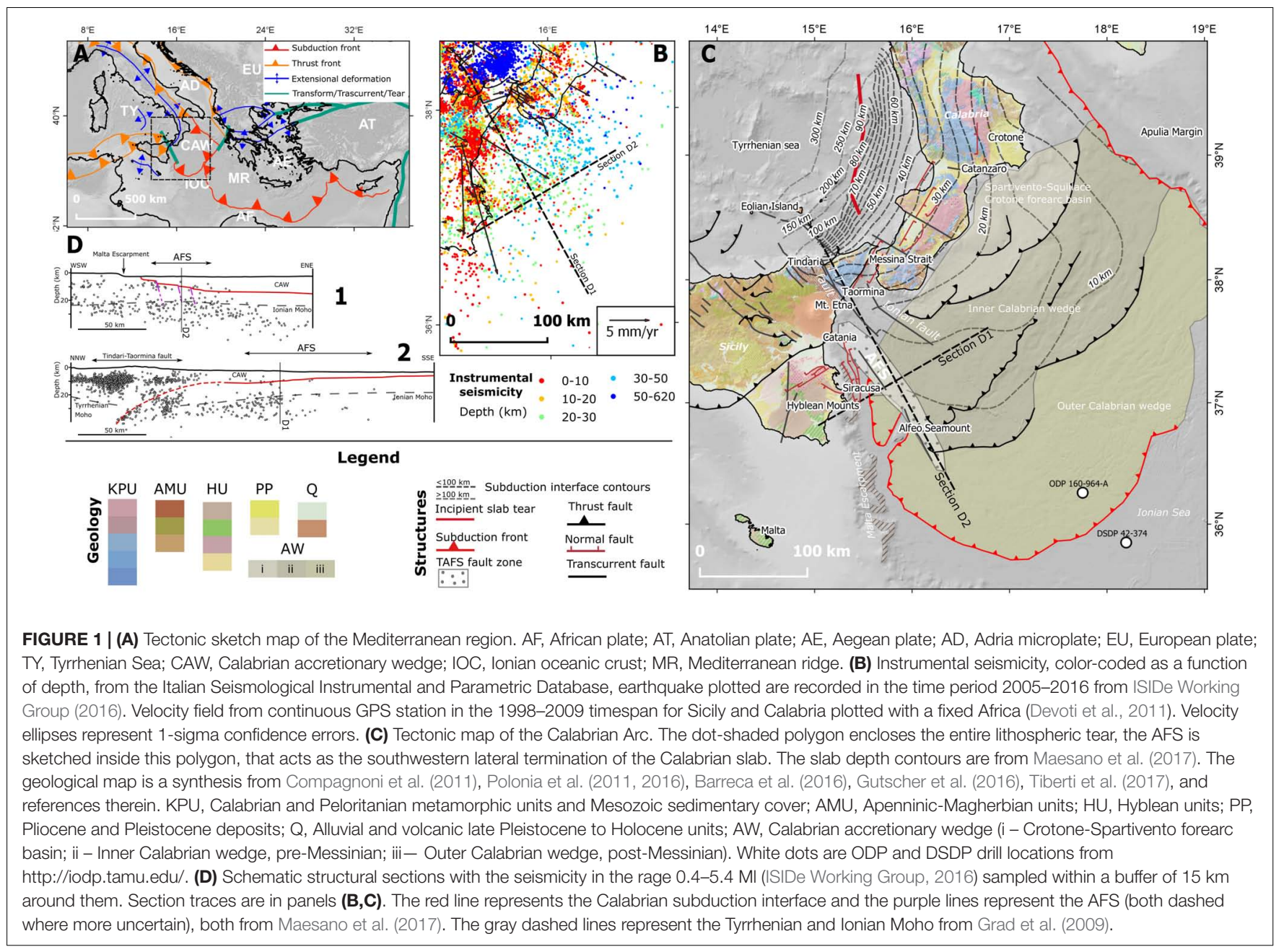

subduction interface. Based on independent constraints, such as velocity and gravity models, Dellong et al. (2018) confirmed both the location of the Alfeo Fault System and its role as a STEP. They confirmed that the Alfeo Fault System seems to be an active fault affecting the whole crust reaching the mantle and ruled out the Ionian Fault as a major structural element because it is limited to shallow crustal depths.

In this work, we performed a detailed analysis of the Alfeo Fault System using a large dataset of seismic reflection profiles integrated with recently published data to quantitatively describe its spatial and temporal evolution. We confirm its role as a major lithospheric tear that affects the whole Calabrian slab and conclude that the southward propagation and vertical displacement rates of the AFS significantly slowed down in the last 1.3 Myr likewise the subduction process associated to its development.

\section{DATA AND METHOD}

The dataset used to study the Alfeo Fault System is made of a dense set of $2 \mathrm{D}$ seismic reflection profiles coming from four different surveys with different acquisition parameters (Table 1).
Collectively, the 39 seismic profiles located within the study area sum up to a length of $4,143 \mathrm{~km}$, covering an area of $67,500 \mathrm{~km}^{2}$ (Figure 2). This dataset was also integrated with the high-resolution profiles published by Gutscher et al. (2016).

The interpretation of seismic reflection data focused on the following aspects: (1) the picking of the horizons bounding the stratigraphic units (Figure 2 and Table 2) derived from previous studies and ODP and DSDP $\operatorname{logs}^{1}$ in the region, (2) the identification of the fault segments that make up the Alfeo Fault System at depth, and (3) the picking of the stratigraphic unconformities. To measure the vertical offset along the Alfeo Fault System, we adopted the subduction interface mapped by Maesano et al. (2017) as a reference marker.

The time-to-depth conversion of the data obtained from the interpretation of the seismic reflection profiles was the most critical step for the geometrical reconstruction of the Alfeo Fault System and the quantitative assessment of its offsets because no direct information exists in the study area on the seismic velocity of the subsurface units. To deal with the uncertainty due to this lack of direct information, we compared three different velocity

\footnotetext{
${ }^{1}$ http://iodp.tamu.edu/
} 
TABLE 1 | Characteristics of the seismic reflection dataset.

\begin{tabular}{|c|c|c|c|c|c|c|c|c|c|c|}
\hline \multirow[b]{2}{*}{ Survey } & \multirow[b]{2}{*}{$\begin{array}{l}\text { Number of } \\
\text { lines }\end{array}$} & \multirow[b]{2}{*}{$\begin{array}{c}\text { Total } \\
\text { length }(\mathbf{k m})\end{array}$} & \multirow[b]{2}{*}{$\begin{array}{c}\text { Record } \\
\text { length (s) }\end{array}$} & \multicolumn{7}{|c|}{ Acquisition parameters } \\
\hline & & & & $\begin{array}{l}\text { Source } \\
\text { type }\end{array}$ & $\begin{array}{c}\text { Source } \\
\text { power (c.i.) }\end{array}$ & $\begin{array}{c}\text { Source } \\
\text { depth (m) }\end{array}$ & $\begin{array}{l}\text { Streamer } \\
\text { depth (m) }\end{array}$ & $\begin{array}{l}\text { Streamer } \\
\text { length }(\mathrm{m})\end{array}$ & $\begin{array}{l}\text { Shot point } \\
\text { interval (m) }\end{array}$ & $\begin{array}{c}\text { Group } \\
\text { interval (m) }\end{array}$ \\
\hline CA99 & 8 & 1581.0 & $6-12$ & Airgun Array & 3410 & 6 & 8 & 6000 & 25 & 12.5 \\
\hline MEM07 & 15 & 1514.3 & 12 & Airgun Array & 2200 & 6 & 8 & 7200 & 37.5 & 12.5 \\
\hline CROP & 7 & 714.2 & $17-20$ & High Pressure Airgun & 140 bar & 6 & 12 & 4500 & 62.5 & 25 \\
\hline \multirow[t]{3}{*}{ Etnaseis } & 6 & 333.0 & $11-17$ & Airgun array & 840 & 23 & $20^{1}$ & $4475^{1}$ & $42.5^{3}$ & 25 \\
\hline & & & & & 3810 & & $21^{2}$ & $2375^{2}$ & $45^{4}$ & 25 \\
\hline & & & & & & & & & $50^{2}$ & \\
\hline
\end{tabular}

The acquisition source power is conventionally expressed in cubic inches (c.i.) except for the CROP survey (bar). Etnaseis seismic line numbers as in Nicolich et al. (2000): ${ }^{1} E 1, E 2, E 6 ;{ }^{2} E 3, E 5 ;{ }^{3} E 6 ;{ }^{4} E 1, E 2$.

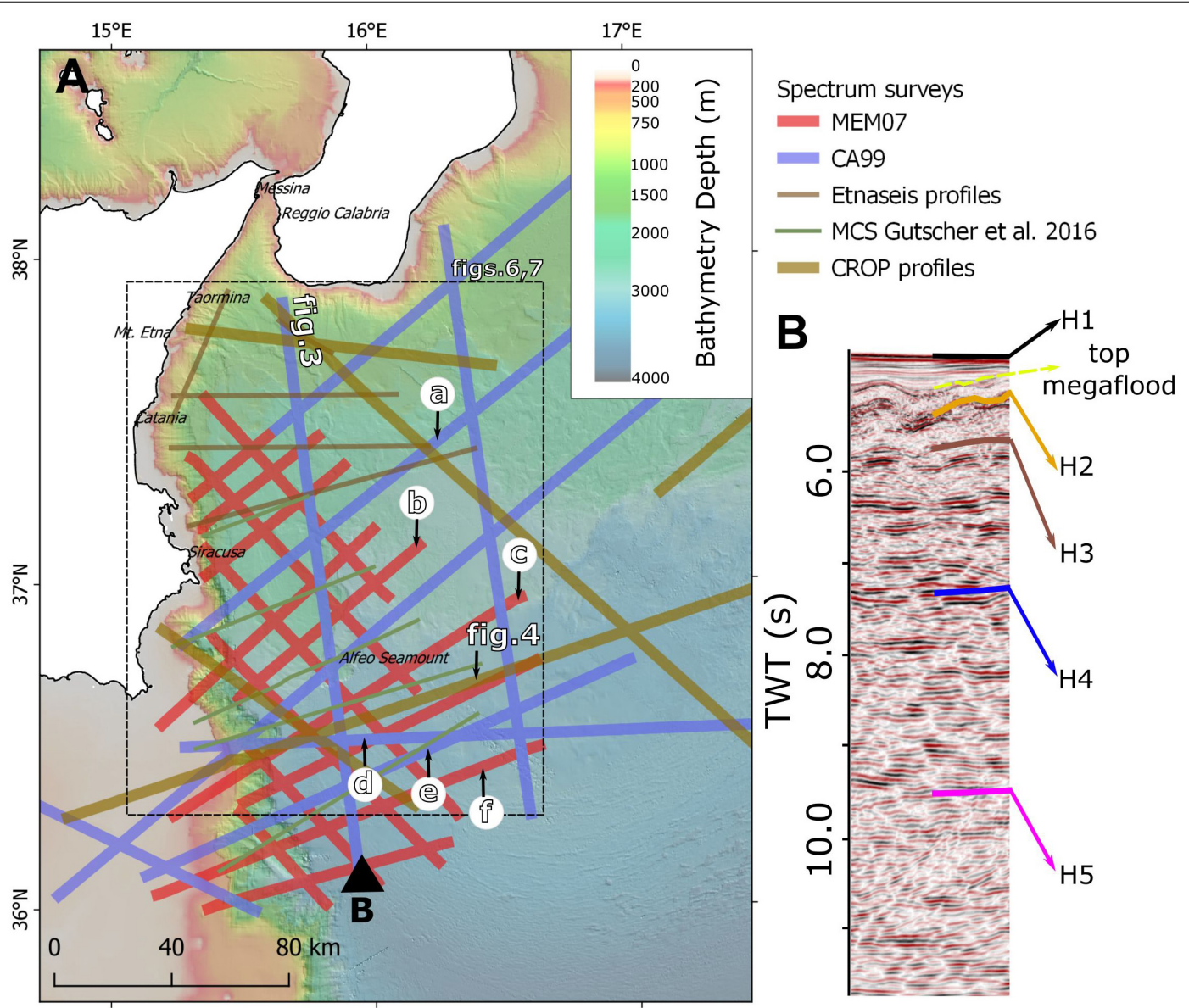

FIGURE 2 | (A) Location map of the 2D-surveys used in this work (see Table $\mathbf{1}$ for details), along with the section segments shown in Figures 3-5. (B) Seismic log and seismo-stratigraphy scheme and mapped horizons common to all seismic lines shown in Figures $\mathbf{3}-\mathbf{6}$. The location of the seismic log is shown by the black triangle in panel (A). H1, Seafloor reflector; H2, Regional angular unconformity at the top of U2. Where U2 is absent, it represents the top of U6 (Minelli and Faccenna, 2010; Polonia et al., 2011); H3, high-amplitude reflector representing the unconformity and correlative conformity at the top of U3 (Gallais et al., 2011 , 2012; Polonia et al., 2011); H4, Planar and continuous reflector representing the top of U4 (Gallais et al., 2011); H5, high-amplitude/low-frequency reflectors identified in most of the seismic lines and representing the top of U5 (Gallais et al., 2011). See the description of seismo-stratigraphic units in Table 2.

models derived from reflection and refraction seismic surveys (Table 3). Model \#1 is based on the velocity analysis performed by Gallais et al. (2011); Model \#2 is based on the seismic refraction experiment performed by de Voogd et al. (1992); Model \#3 is based on a combination of published data, wide-angle seismic data, and stacking velocities, as proposed by Maesano et al. (2017). All three models consist of the same four layers (Table 3). For layers L1, L2, and L3, we always adopt constant interval 
TABLE 2 | Seismo-stratigraphic units.

\begin{tabular}{|c|c|c|c|c|}
\hline & ID & Geologic description and seismo-stratigraphic facies & Age & References \\
\hline \multirow[t]{7}{*}{ Units } & U1 & $\begin{array}{l}\text { Unconsolidated siliciclastic turbiditic and distal deposits } \\
\text { often associated with chaotic bodies at the base of the } \\
\text { succession. Analog of units PP and Q of Figure } 1 . \\
\text { Well-layered HF-LA reflectors with the presence of } \\
\text { numerous unconformities. }\end{array}$ & Pliocene - Holocene & $\begin{array}{l}\text { Minelli and Faccenna, 2010; Polonia } \\
\text { et al., 2011, 2016; ODP 160-964 }\end{array}$ \\
\hline & U2 & $\begin{array}{l}\text { Salt-bearing complex related to the tectonic stacking of } \\
\text { Messinian evaporites. } \\
\text { HA and quite continuous reflectors at the top, overlying a } \\
\text { highly homogeneous reflection-free zone bounded at the } \\
\text { base by a planar HA reflector. }\end{array}$ & Messinian & $\begin{array}{l}\text { Finetti and Morelli, 1972; Polonia et al., } \\
\text { 2011; Gallais et al., 2012; ODP } \\
\text { 160-964; DSDP 42-374 }\end{array}$ \\
\hline & U3 & $\begin{array}{l}\text { Siliciclastic deposits (analog of outcropping units in Sicily } \\
\text { and Southern Apennines) marked by on-lap on U4. } \\
\text { Alternating HA-LF, subparallel reflectors, bounded at the top } \\
\text { by a continuous HA reflector; this unit can be differentiated } \\
\text { from the accretionary wedge only in the external regions. }\end{array}$ & Paleocene (?) - Tortonian & $\begin{array}{l}\text { Minelli and Faccenna, 2010; Gallais } \\
\text { et al., 2011; Polonia et al., } 2011\end{array}$ \\
\hline & U4 & $\begin{array}{l}\text { Pelagic carbonate sediments (analog of outcropping units } \\
\text { in Sicily and Southern Apennines, AMU unit in Figure 1), } \\
\text { covering the lonian oceanic crust. } \\
\text { LA-LF subparallel reflectors characterized at the base by } \\
\text { high-amplitude reflectors } 0.3 \mathrm{~s} \text { TWT thick. }\end{array}$ & Triassic - Cretaceous & \\
\hline & U5 & $\begin{array}{l}\text { Noisy seismic facies located under HA-LF seismic } \\
\text { reflections at } 8.5 \mathrm{~s} \text { TWT in the external area of the } \\
\text { accretionary wedge. }\end{array}$ & & $\begin{array}{l}\text { Catalano et al., 2001; Stampfli and } \\
\text { Borel, 2002; Müller et al., } 2008\end{array}$ \\
\hline & U6 & $\begin{array}{l}\text { Calabrian Accretionary Wedge made up by the tectonic } \\
\text { stacking of U3, U4 (AMU unit in Figure 1), and of the } \\
\text { Calabride units (KPU in Figure 1). } \\
\text { Chaotic and highly deformed LA seismic facies with some } \\
\text { LF-HA discontinuous reflectors. }\end{array}$ & Mesozoic - Pliocene & $\begin{array}{l}\text { Minelli and Faccenna, 2010; Polonia } \\
\text { et al., 2011; Gallais et al., } 2012\end{array}$ \\
\hline & U9 & $\begin{array}{l}\text { Hyblean platform carbonates. Analog of HU unit in } \\
\text { Figure } 1 . \\
\text { Layered HF seismic facies in the upper part; transparent } \\
\text { seismic facies in the lower part. }\end{array}$ & Mesozoic - Miocene & \\
\hline
\end{tabular}

HA, high amplitude; LA, low amplitude; HF, high frequency; LF, low frequency.

TABLE 3 | Velocity models.

\begin{tabular}{|c|c|c|c|c|c|c|}
\hline \multirow[b]{2}{*}{ Layer } & \multirow[b]{2}{*}{ Layer name } & \multirow[b]{2}{*}{ Unit } & \multirow{2}{*}{$\begin{array}{l}\text { Model \#1 } \\
\text { V (m/s) }\end{array}$} & \multirow{2}{*}{$\begin{array}{l}\text { Model \#2 } \\
\text { V (m/s) }\end{array}$} & \multicolumn{2}{|c|}{ Model \#3 } \\
\hline & & & & & $V(m / s)$ & $K(1 / s)$ \\
\hline L1 & Water & n.a. & 1500 & 1500 & 1500 & 0 \\
\hline L2 & Pliocene-Pleistocene unit & U1 & 1800-2000 & 1900 & 1900 & 0 \\
\hline L3 & Messinian wedge & U2 & $4200-4500$ & 4200 & 4000 & 0 \\
\hline$\llcorner 4$ & Pre-Messinian wedge and units & U6 & 3000-3200 & 3000-3800 & 2500 & $0.15-0.50$ \\
\hline
\end{tabular}

velocities. For L4, we adopt a constant velocity in Model \#1 and Model \#2, and a 3D instantaneous velocity function (Marsden, 1992; Maesano and D’Ambrogi, 2017) in Model \#3.

The boundary horizons of the four layers were depth converted using the algorithm by Maesano and D'Ambrogi (2017). This algorithm is designed to perform time-to-depth conversion of complex geometries defined in 3D by adopting a layer-cake velocity model, also considering layers either with a variable velocity gradient on a given horizon or with velocity varying with depth. After having built the $3 \mathrm{D}$ velocity model, the fault segments were depth converted using velocity parameters corresponding to the position of each fault sample point within the velocity model. We then interpolated the results of the time-depth conversion to produce a $3 \mathrm{D}$ geological model constituted by the seafloor surface, the top of the Messinian surface, the subduction interface, and the AFS faults segments.

The top of the Messinian horizon was interpolated using anisotropic ordinary kriging (major axis ratio 1.5 , oriented $\mathrm{N} 163^{\circ}$ ) considering the preferential orientation of structural features (basin elongation and faults) observed in a preliminary interpolation phase. The subduction interface geometry was obtained with the Delaunay triangulation and smoothing made by Maesano et al. (2017). Similarly, fault surfaces were interpolated between and among different seismic profiles with a Delaunay triangulation. 
We used this 3D geological model to analyze the relationships between the Pliocene-Holocene sedimentary basins and the Alfeo Fault System activity, and then performed a quantitative estimate of the subduction interface offset.

\section{RESULTS}

\section{Seismostratigraphy}

The analysis of the seismic profiles led to the identification of five main horizons separating the major seismostratigraphic units. A secondary horizon was mapped within the shallower seismostratigraphic units and was interpreted as the results of one or more post-Messinian megaflood events. The characteristics of mapped horizons are shown in Figure $\mathbf{2 B}$, and those of the seismostratigraphic units are summarized in Table 2 (see also Supplementary Figure 1). The shallower part of all seismic profiles shows the presence of well-layered high-frequency and low-amplitude reflectors interpreted as unconsolidated PlioceneHolocene sediments (U1) lying over a transparent seismic facies with discontinuous high-amplitude reflectors in the upper part that we interpret as a characteristic of the Messinian evaporites (U2). This unit constitutes a huge post-Messinian body in the frontal part of the accretionary wedge and forms also a thick wedge juxtaposed to the northern flank of the Alfeo Seamount, which is a Mesozoic structural high of African crust (Figure 3). A set of sub-horizontal high-amplitude low-frequency reflectors at the southern termination of the profile in Figure 3 were interpreted as representing the whole undisturbed MesoCenozoic sedimentary succession (U3, U4) deposited above the Ionian oceanic crust (U5). In the northern part of the study area, strong reflectors also depict the deepening of the Ionian crust under the accretionary wedge. The subduction interface was mapped as the separation between the chaotic seismic facies of the Calabrian Accretionary Wedge (U6) and the layered facies of the Ionian basin sedimentary covers (U3, U4). The frontal part of the accretionary wedge reaches the Alfeo Seamount in the middle of the profile (Figure 3). South of the Alfeo Seamount, the profile shows the lateral spreading of the post-Messinian wedge toward SSW.

\section{Deep-Seated Segments of the Alfeo Fault System}

The high penetration of the multichannel seismic data allowed us to image the geometry of the AFS within profiles of up to $10 \mathrm{~s}$ TWT (Figure 4). We could thus identify the AFS as composed by a network of high-angle faults juxtaposing the Calabrian Accretionary Wedge (pre-Messinian; U6), in the hanging wall, with the undisturbed Mesozoic-Upper Miocene succession (U3 and U4), in the footwall. The master fault, systematically located to the southwest, shows an offset as large as 1,000 ms.

The shallower unit (U1) has a roughly constant thickness in the entire profile except for the central part where the thickness increases westwardly within an asymmetric basin controlled by a shallow fault (hereinafter Shallow Syn-Tectonic Basin, SSTB) located above the AFS (Figure 4).

The AFS at depth shows up as an abrupt truncation of the Meso-Cenozoic reflectors (see also Sections from A to E in Figure 5, which intersect the AFS almost orthogonally). In the hanging wall, U3 is involved in the deformation of the accretionary wedge whereas the top of Mesozoic carbonates (H4) is still recognizable under the subduction interface and is affected by a cumulative vertical offset progressively decreasing southeastwardly from a maximum of $1700 \mathrm{~ms}$ to $150 \mathrm{~ms}$ (Figure 5, Sections from A to E). Farther south, only bending of the units below the subduction interface (U3, U4, and U5) is visible (Figure 5, Section F).

The seismic profiles located in the northern part of the study area show four subparallel main segments of the AFS (F1-F4 in Figure 5, Section A and Figure 3 in the northern part), then two main fault segments can be recognized in the next profile to the south (Figure 5, Section B), and farther south only one segment (Figure 5, Section C onward).

A single major fault segment represents the AFS to the south of the Alfeo Seamount. This segment offsets the Ionian oceanic crust
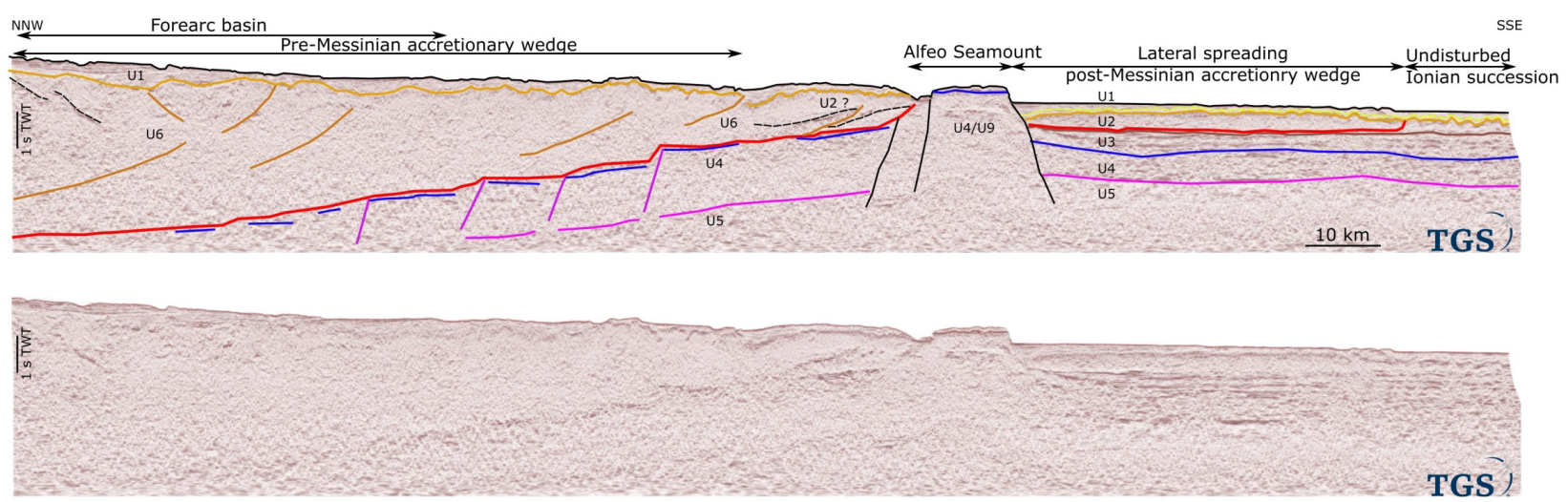

FIGURE 3 | Seismic reflection profile across the Calabrian accretionary wedge, the Alfeo seamount and the outer post-Messinian accretionary wedge. See Figure 2A for location. The data presented here are subject to a confidentiality agreement with TGS that does not allow us to show the absolute two-way-time on the seismic profiles. 

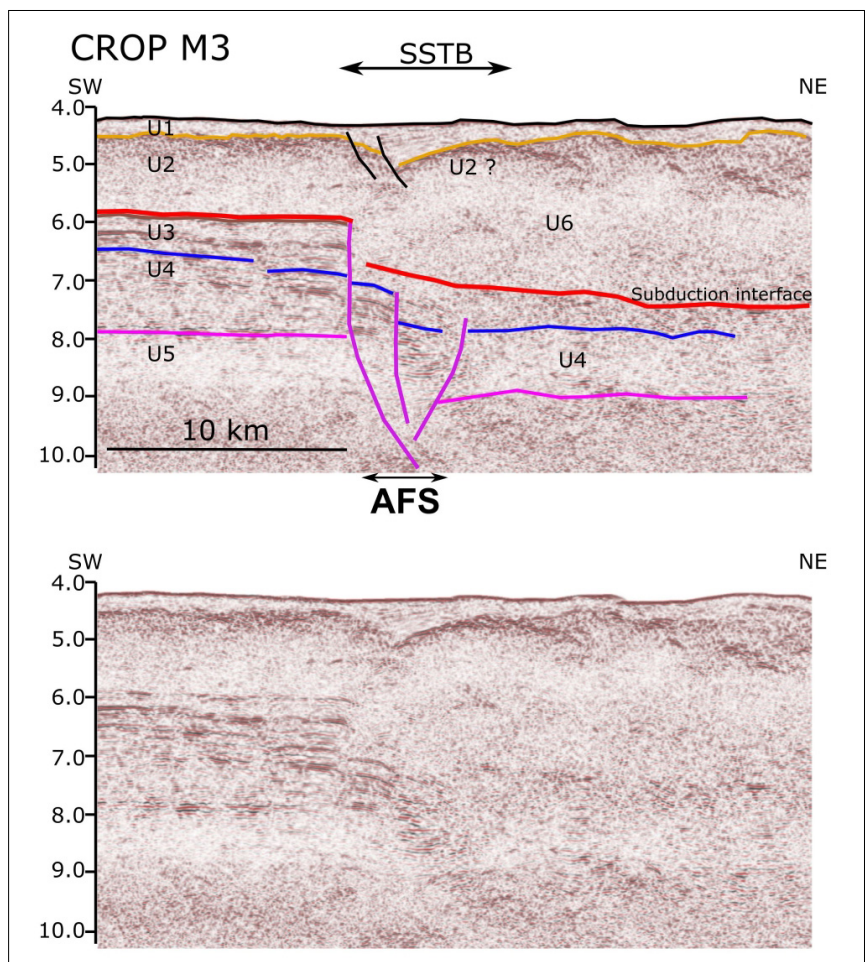

FIGURE 4 | Interpretation of the CROP M3 multichannel seismic profiles across the AFS and showing the Shallow Syn-Tectonic Basin (SSTB), see Figure 2 for location. Data available from CNR-ISMAR (http://www.crop.cnr.it/).

(U5) and the overlaying Meso-Cenozoic succession (Figure 5, Sections C-E). Minor faults, with both synthetic and antithetic attitude, can be observed (Figure 5, Sections D, and Figure 4). The southernmost seismic profile (Section F; Figure 5) shows no clear evidence of offset of the subduction interface due to the activity of the AFS. Here both the lower plate units and the subduction interface are just bent, and some minor displacement can only be observed within the Mesozoic succession (U4).

A common feature of all the AFS master fault segments is that they do not propagate through the accretionary wedge (Figure 6). Instead, we recognized the systematic presence of recent (Pliocene-Holocene) SSTBs (Figure 5), which seem to be controlled by shallow normal faults, right above the deep-seated AFS segments. In the sector south of the Alfeo Seamount, we recognize only one main SSTB. In the southernmost seismic profile (Figure 5, Section F), we found only a broader and thinner basin compared to the other seismic profiles, and no evidence of basin-bounding faults. Notice that the basin lies above the zone where the lower plate units and the subduction interface are bent.

A close look to all the seismic profiles of Figures 4, 5 allows us to verify that there is no direct connection between the faults cutting the upper plate (accretionary wedge) and the faults cutting the lower plate (Figure 6 for a schematic view). This observation is here interpreted as the result of a mechanical decoupling acting at the base of the accretionary wedge (U6). The SSTB observed at the seafloor are here interpreted as a zone of diffuse deformation at the shallow level in response to the deformation of the AFS faults below the decoupling level.

\section{Alfeo Fault System Displacement Distribution}

The time-depth converted $3 \mathrm{D}$ model includes the seafloor, the base of the Pliocene-Holocene succession, the subduction interface, and four fault segments. Using this model, we first analyzed the mutual relationships between the structures associated with the AFS and peculiar geometric features of the subduction interface in their vicinity; then, we quantified the offset distribution along the AFS adopting the subduction interface as the most representative marker for taking the offset point measurements. This analysis revealed the presence of two distinct sectors of the AFS, northern and southern, whose transition occurs in correspondence of the Alfeo Seamount (Figure 7). The two sectors show different levels of the maturity and complexity of the fault system described in the following.

In the northern sector, there are four major NW-SE fault segments (F1-F4; Figure 7A) identified by correlating individual faults across different profiles. They displace the subduction interface and put the innermost part of the accretionary wedge into contact with the outer accretionary wedge (Figure 1C). The northernmost of these segments (F4) can be interpreted as the offshore continuation of the Tindari-Taormina fault (Figures 1C, 7A). Southward, the fault segments F2-3 transfers the deformation onto F1, which slightly changes its strike in correspondence of the Alfeo Seamount. In the southern sector, there is a single major fault segment, roughly oriented N150, that is the southward continuation of F1.

We took point-measures of the vertical throw of all these fault segments on 20 sections, drawn orthogonally to the strike of main fault segments at a regular spacing of $4 \mathrm{~km}$. In correspondence of the Alfeo Seamount, there is a gap of $24 \mathrm{~km}$ where the offset could not be measured. We then projected the summed vertical throw onto a single profile. This summation yields a maximum value of $6,000 \mathrm{~m}$ in the northernmost sector, where it includes the contribution of all the four segments (F1-F4). Then, the offset decreases rapidly to about 2,000 m toward the Alfeo Seamount. South of the Alfeo Seamount the vertical offset is due to F1 only and tapers gradually down to zero. In the southernmost seismic section (Figure 5, Section F) there is evidence of no offset on the subduction interface. In correspondence of the ideal continuation of the AFS there is a $10-\mathrm{km}$-wide zone of bending of the lower crust and subsidence of the overlying post-Messinian accretionary wedge.

\section{Pliocene-Holocene Shallow Syn-Tectonic Basins}

We used the depth-converted version of the seismic interpretation to interpolate the base of the Pliocene horizon 


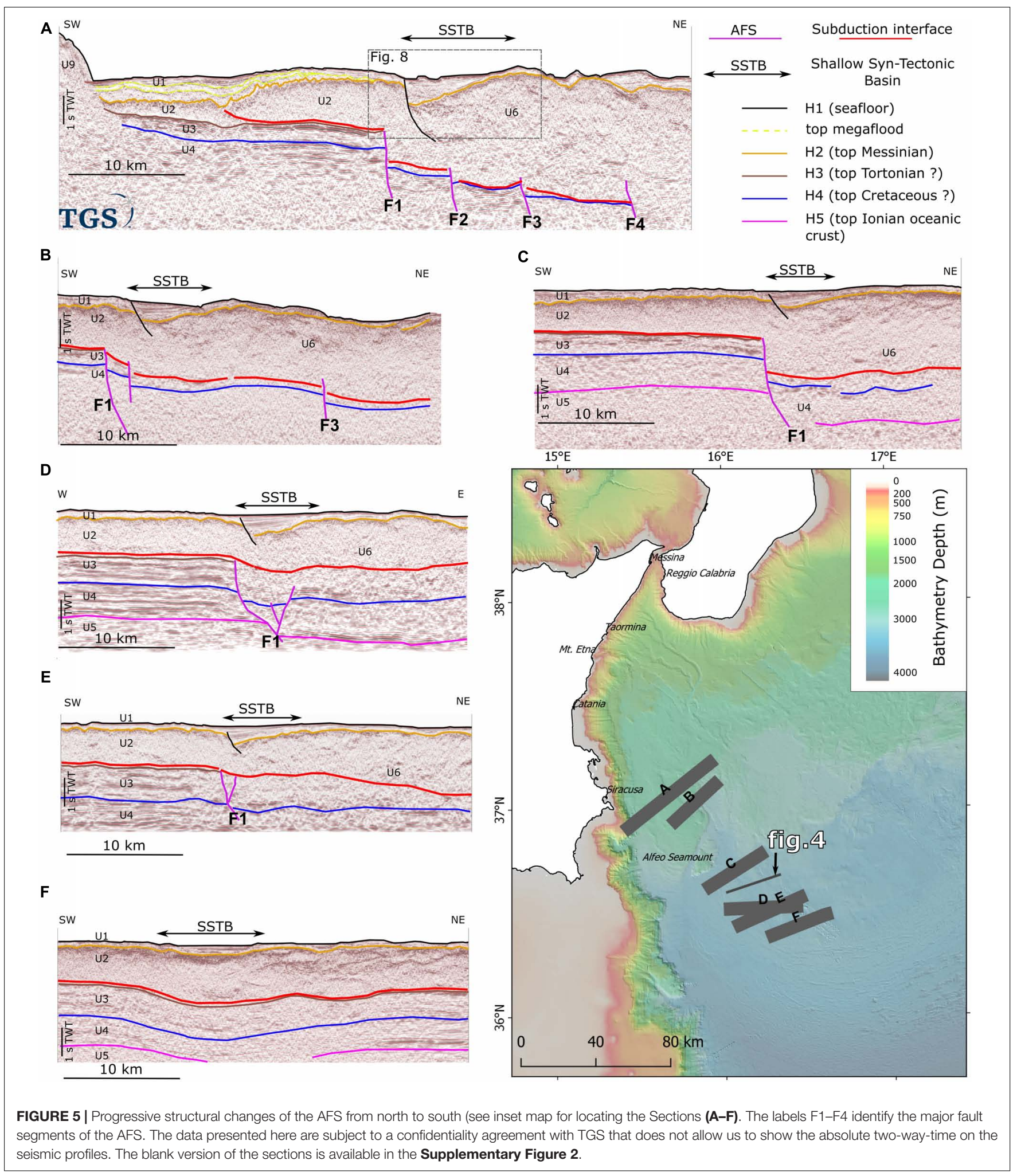

(H2) and to explore the thickness variations of the PlioceneHolocene succession (U1) along the AFS and its surroundings (Figure 8). Overall, the average thickness of $\mathrm{U} 1$ is about $280 \mathrm{~m}$, but some remarkable deviations from this average can be observed in all the seismic profiles transversal to the AFS (Figures 4, 5). These are thicker sediment infill of the SSTBs characterized by the presence of various unconformities within U1 (Figure 9). We identified at least three main sub-units of U1 


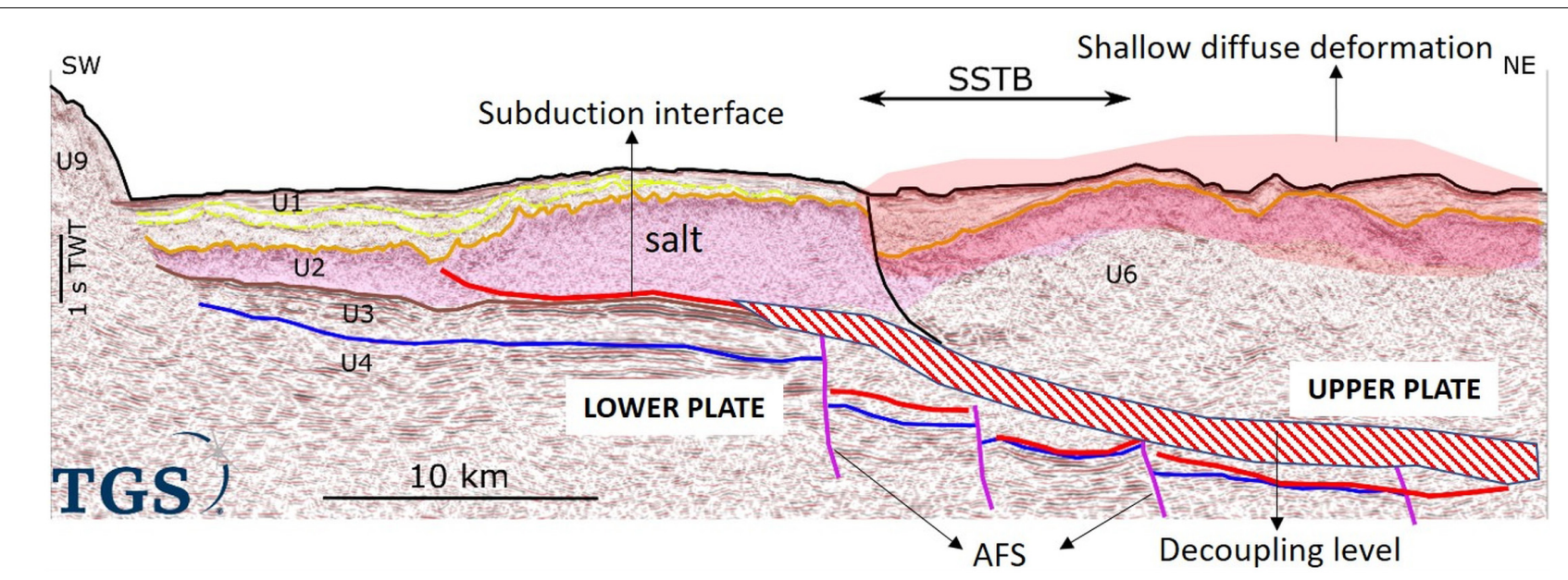

FIGURE 6 | Synthesis of the main structural elements within and around the Alfeo Fault System outlined onto the seismic profile shown in Figure 5A. Mechanical decoupling between the structural elements forming the Alfeo Fault System. The red-dashed area marks a layer immediately above the clearly offset subduction interface which seems to act as a barrier preventing the upward propagation of lower-plate faults and favoring the downward curvature of the upper-plate shallow faults. The red-shaded area indicates the occurrence of diffuse non-mappable shallow deformation on the AFS hanging wall.

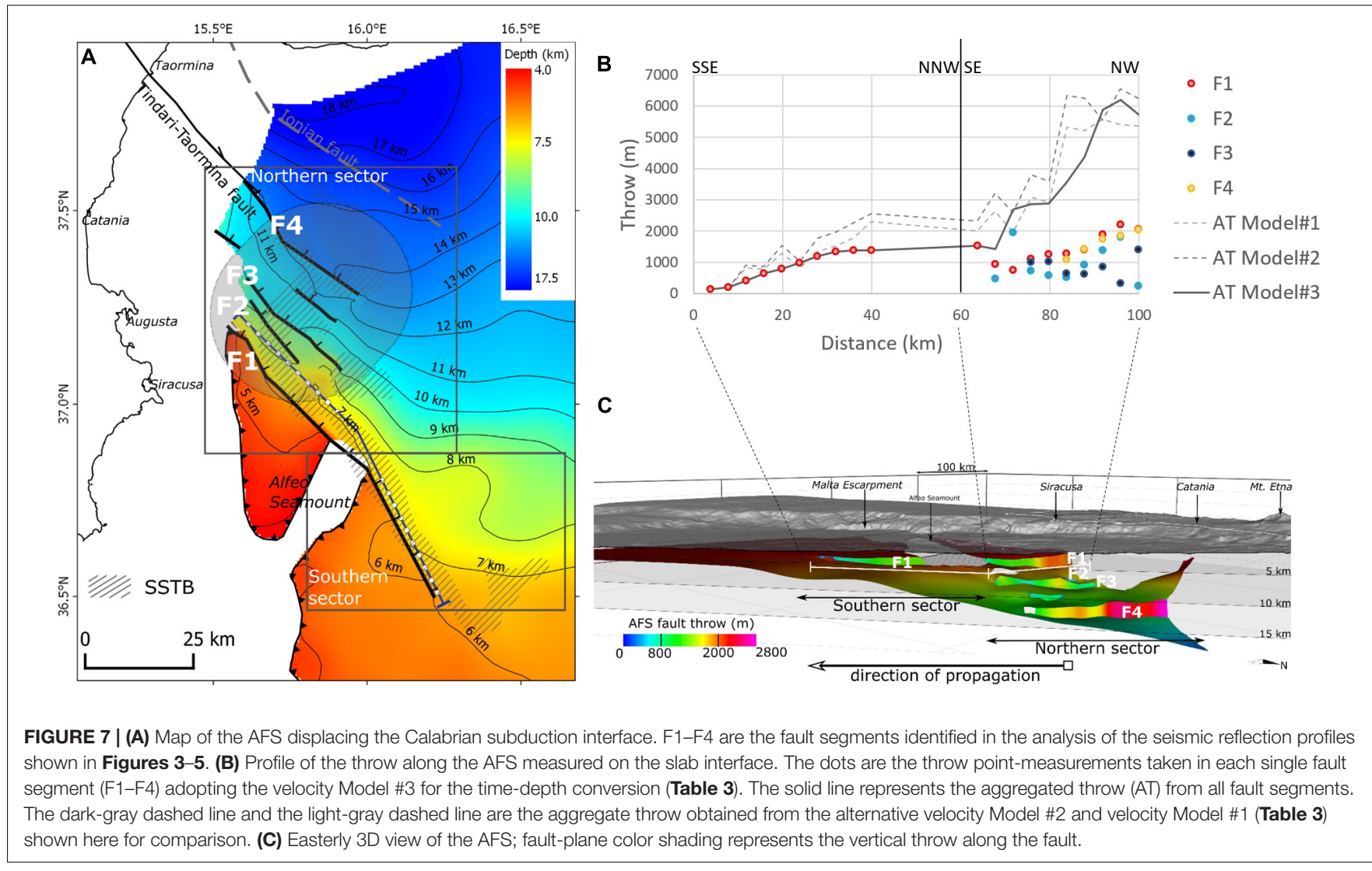

within these SSTBs (Figure 9). Sub-unit U1a is characterized by low-amplitude/high-frequency reflectors subparallel to the base of Pliocene unconformity (H2) with a thickness ranging between 100 and $160 \mathrm{~m}$ that we interpret as pretectonic pelagic sedimentation. Sub-unit U1b is characterized by chaotic seismic facies that we interpreted as a series of turbiditic successions. Sub-unit U1c is a syn-tectonic package of low-amplitude/high-frequency reflectors with fan-shaped growth strata.

Along the trace of the AFS (the area included in the swath profile of Figure 8A), U1 forms one elongated basin in the southwestern part and by a more complex 

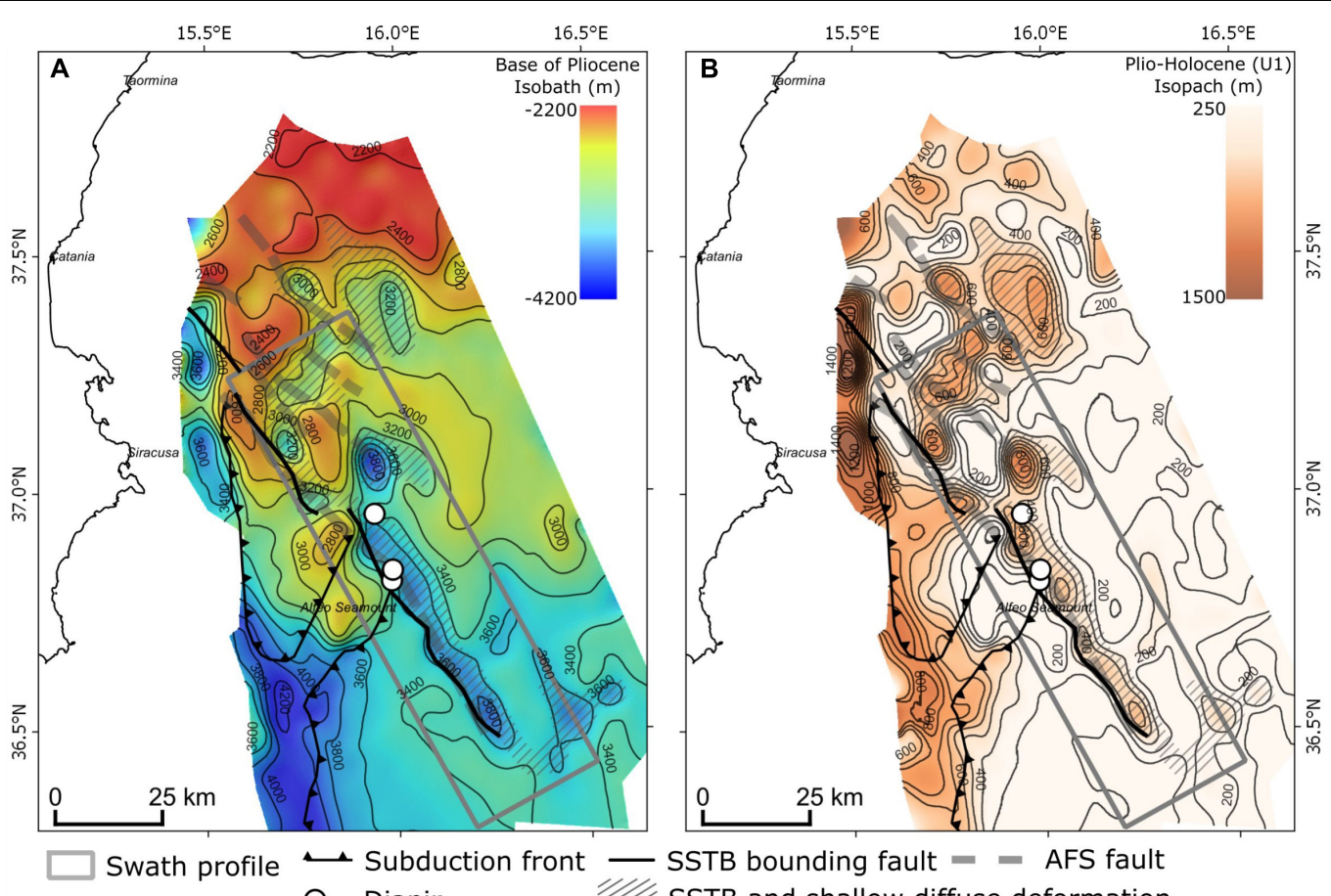

SSTB bounding fault $-=$ AFS fault

SSTB and shallow diffuse deformation

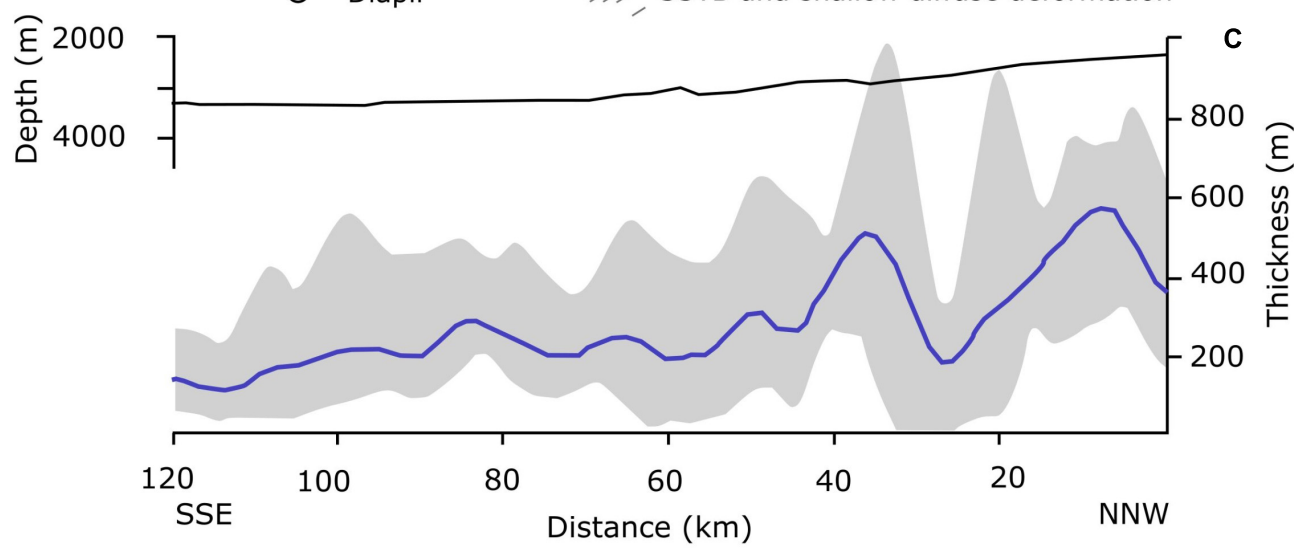

FIGURE 8 | (A) Map of the base of Pliocene. (B) Map of the thickness of the Pliocene-Holocene unit obtained by subtracting a bathymetric surface (smoothed to avoid the influence of small-scale topographic features of the seafloor) from the base of the Pliocene. (C) Swath profile (outlined by the gray rectangle in panels $\mathbf{A}, \mathbf{B}$ ) showing the average thickness (blue line) of the Pliocene-Holocene unit, along with the envelope of minimum and maximum values (gray shading), and the average depth of the seafloor. Seafloor fault traces in (A,B) are redrawn from Gutscher et al. (2016). In all panels, the star marks the location of the Shallow Syn-Tectonic Basin (SSTB) shown in the seismic sections in Figures 4, 5.

pattern of depocenters in the area to the north of the Alfeo Seamount.

The U1 thickest part occurs in correspondence of the Malta Escarpment (Figure 1) at the base of which early Zanclean chaotic bodies due to mass flow lay above H2 (Figures 5A, 6). In the seismic reflection profiles, U1 deposits do not show evidence of syn-sedimentary tectonic deformation along the Malta Escarpment (leftmost part of the section in Figure 6), whereas they are deformed farther northeast, on the top of the Messinian evaporites by the syn-sedimentary accretion of the wedge and by saline diapirism. The western part of Section A (Figures 5, 6) shows a chaotic body, possibly related to one or two major mega-flood events that drape the western lateral toe of the accretionary wedge.

These observations about the Pliocene-Holocene unit (U1) thickness allowed us to verify the lateral continuity of the SSTBs (Figure 8) that are associated with the presence of the deepseated elements of the AFS as identified in the seismic reflection profiles (Figure 5).

The swath profile (Figure 8C; $120 \mathrm{~km}$ long, $32 \mathrm{~km}$ wide, long side oriented $\mathrm{N} 150^{\circ}$ ) shows that the maximum and mean thickness values of the Pliocene-Holocene unit (U1) generally decrease from NW to SE. The minimum thickness values show the same trend, although with less variation. This lower variability 


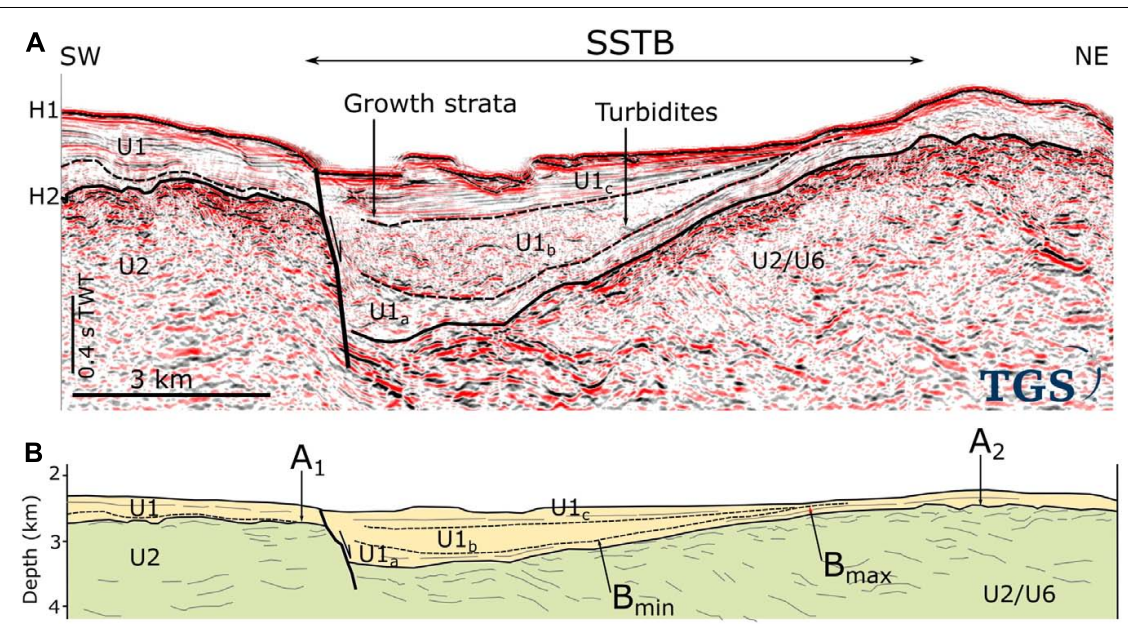

FIGURE 9 | (A) Seismo-stratigraphic detail of Section A in Figure 5. (B) Depth-converted line drawing. A1 and A2 are two points of measurement of the U1 succession taken far away from the shallow fault that controls the syn-tectonic Pliocene-Holocene basin (SSTB). Bmin and Bmax represent the minimum and maximum thickness, respectively, of U1a in which the reflectors are subparallel to the Top Messinian horizon. Refer to the text, Figure $\mathbf{2 B}$, and Table $\mathbf{2}$ for the description of the involved horizons and units.

may suggest that the pelagic sedimentation in the area has rather uniform rates outside the zones affected by the activity of shallow faults controlling the SSTBs. If we take the minimum thickness as a reference proxy, then the variability of the mean thickness is only due to the presence of fault-controlled depocenters (SSTB), with a maximum thickness of up to $1000 \mathrm{~m}$ in the northern part of the profile. The SSTB located south of the Alfeo Seamount (Figure 8) can be correlated across various seismic profiles (Figures 4,5) showing that the thickness of the recent deposits decreases from NNW to SSE. This decrease suggests that the vertical offset of the shallow fault that border the SSTB should reduce accordingly, as also shown by the seismic sections in Figures 4, 5 (Sections C, D, E).

\section{DISCUSSION}

The interpretation of the seismic profiles, and particularly of the closely spaced MEM07 survey (Figure 2), allowed us to unveil several peculiar aspects of the AFS. We could (1) follow and map the AFS at depth for over $180 \mathrm{~km}$ in the Ionian offshore; (2) attribute the deformation at shallow depth to the interference between the AFS activity at depth and the previously structured upper-plate accretionary wedge; and (3) verify that there is no direct connection between the faults cutting the upper plate (accretionary wedge) and the faults cutting the lower plate. We will now discuss our observations and interpretations in the context of the subduction process of the African plate as the driving mechanism of the ongoing propagation of the AFS toward the outer part of the accretionary wedge (Figure 10A).

\section{Fault Up-Dip Propagation and Decoupling}

Previous studies already outlined the narrow zone of deformation associated to the AFS (Polonia et al., 2011; Gallais et al., 2013;
Gutscher et al., 2016), characterized by fault-controlled shallow basins and related with a master fault at depth. Differently, from our present results, Del Ben et al. (2008) and Polonia et al. (2017b) interpreted the shallow faults associated with the syn-tectonic basins as directly connected with the deeper part of the AFS.

We here showed that the Pliocene-Holocene SSTBs are systematically located above the AFS deep-seated segments (Figures 4-6). These SSTBs developed on top of the Messinian unconformity $(\mathrm{H} 2)$ and were filled by deposits characterized by growth strata that mimic the development of a roll-over anticline with the maximum thickness near the basin-bounding fault (Figure 9). The shallow faults neither show any direct connection with the deep-seated segments of the AFS nor they have any geometrical compatibility with them because they are downward curved (listric) at shallow depth within the Messinian evaporites (U2; Figure 6). Conversely, the upper tips of the AFS segments do not propagate toward the surface (Figures 4-6). They systematically displace the subduction interface but end immediately above it within the very base of the upper plate, and below the Messinian evaporites (U2). We can thus hypothesize that the mechanical heterogeneity that exists at the base of the accretionary wedge inhibits the upward propagation of the AFS brittle elements, though not stopping a more diffuse deformation. The separation between shallow and deep-seated faults in our reconstruction must represent a mechanical decoupling between the lower and upper plates (Figure 6). Analog models (e.g., Withjack and Callaway, 2000; Bonini et al., 2015, 2016; Vasquez et al., 2018) support the hypothesis that pre-existing low-angle discontinuities exert an influence on the upward propagation of normal faults.

In the structural configuration of the AFS, this discontinuity can either be represented by the mechanically "weak" layer of the Messinian evaporites or by the crustal thrusts within the accretionary wedge. In the first case, the shallow faults can either be interpreted to be bending-moment faults. In the 


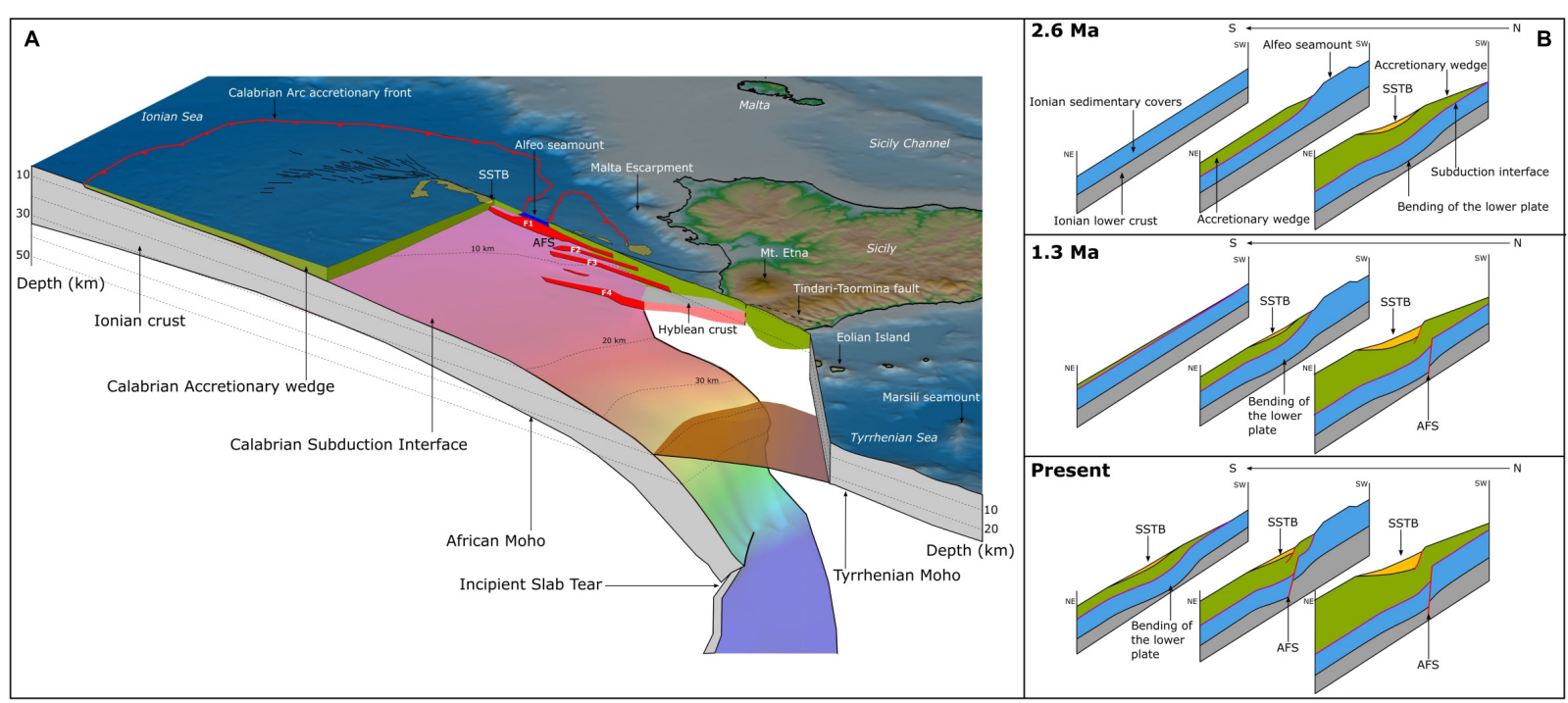

FIGURE 10 | Role and evolution of the Alfeo Fault System (AFS). (A) 3D diagram showing the structural relationships between the different elements at the southwestern lateral termination of the Calabrian north-dipping slab. (B) Space-time schematics of the southward growth and propagation of the Alfeo Fault System.

second case, the shallow faults could be interpreted as being the possible negative reactivation of lateral ramps within the accretionary wedge, kinematically developed in response to the diffuse deformation induced by the activity of the AFS at depth. In both cases, these faults accommodate the differential sinking of the lower plate and the collapse of the accretionary wedge.

Despite the decoupling between the lower and upper plates, there is an evident spatial correspondence between the shallow faults, with their associated SSTBs developed on top of the accretionary wedge, and the AFS underneath (Figures 7, 9). This correspondence is a key factor to constrain the temporal evolution of the AFS and its role in the post-Messinian evolution of the Calabrian accretionary wedge as we will discuss later.

\section{Displacement Analysis and Kinematics}

The subduction interface is the most reliable marker to estimate the vertical displacement produced by the AFS. In this respect, the velocity model adopted for the time-depth conversion is the most critical variable. We thus compared the reference model adopted for this study, in which the velocity of the lowermost layer (L4) increases with increasing depth (Maesano et al., 2017), with two alternative models, one from de Voogd et al. (1992) and the other from Gallais et al. (2012), in which the velocity is constant in all layers (Table 3 ). In general, our reference model predicts lower values of fault throw - in the range of $20-40 \%-$ than the other two models (Figure 7B). However, two main features, the throw maximum cumulative value of 6,000 $\mathrm{m}$ and its decrease from NW to SE along the AFS, are consistently present in all the adopted velocity models (Figures $7 \mathbf{B}, \mathbf{C}$ ). Toward the southernmost tip, the displacement tapers down to zero. This displacement profile is compatible with the development of a scissor-like fault system (mode III of fracture propagation) in which the innermost sector of the shear zone is affected by the maximum displacement that gradually decreases in the direction of propagation (Figure 7A). This mechanism would imply that the kinematics of the AFS should be prevalently normal with a secondary horizontal right-lateral component, that may appear especially in the northern sector.

\section{Age of the Shallow Syn-Tectonic Basins and Activity Rates}

The seismic profile that is shown in Figure 5 - Section A contains an essential element for estimating the age of the SSTBs. The central portion of that profile is enlarged in Figure 9, which shows a more detailed seismo-stratigraphic interpretation in time units (Figure 9A) and its depth-converted version (Figure 9B).

The more distant areas from tectonic deformation (the SW and NE terminations of the profile in Figure 9) show a rather constant thickness of the succession overlying the Messinian unit (U2), which consists of 260-m-thick Pliocene-Holocene pelagic deposits which cover a time interval of 5.3 Myr (A1 and A2 in Figure 9B). This yields an average sedimentation rate of $0.05 \mathrm{~mm} / \mathrm{yr}$ for the Pliocene-Holocene succession. Assuming this sedimentation rate of the pelagic succession as representative for the whole area and the entire time interval, the succession U1a at the base of the SSTB (Bmin and Bmax in Figure 9) should have been deposited in 2.7 Myr. Since the reflectors in succession U1a are subparallel to $\mathrm{H} 2$, we can also assume that $\mathrm{U} 1 \mathrm{a}$ was deposited before the inception of the shallow fault that controls the basin. The apparent drag of succession U1a along this fault also supports this assumption. By subtracting the deposition age of U1a from the age of $\mathrm{H} 2$, we obtain that the basin must have started its development later than 2.6 Ma. Also, we cannot rule out the possibility that the turbiditic flows, for which Polonia et al. (2013) suggest a prevalent NW-SE transport direction, have eroded part of the succession and thus the age of inception of the shallow fault could even be slightly younger. 
Moving along the AFS from north to south by exploring all the transversal seismic profiles, we noted that in the southern sector, the Pliocene-Holocene SSTBs are progressively thinner, and less developed in terms of primary structures within the succession (Figure 5) than in the northern sector. This is also comprehensively shown in the maps and swath profile of Figure 8.

In the northern sector of the study area, the shallow diffuse deformation area (Figure 6) recorded by the Plio-Holocene sediments (Figure 8), which include also the SSTBs, is broader and, in some cases, its geometry is more difficult to outline. This circumstance occurs in correspondence of the deep-seated multiple fault segments whose activity may have influenced the shape of the accommodation space and the consequent areal distribution of the Pliocene-Holocene deposits (Figures 5, 6, 9). The large oversteps between fault segments F1 to F4 suggest that the area to the north of the Alfeo Seamount should have been affected by a significant NE-SW extensional component of deformation (Figure 7). Also, the presence of a non-negligible strike-slip component in the AFS movement at depth could justify the complex arrangement of the deformation recorded by the shallower sedimentary units, likely as the result of restraining bends or stepovers where the different fault segments overlap. The high variability of the maximum thickness observed in the northern sector $(0-40 \mathrm{~km}$ in the swath profile, Figure 8C) across the SSTBs can thus be interpreted as the result of the possible interference recorded by the basins due to the strikeslip component of the underlying AFS segments. However, this remains only a qualitative deduction because our data can only constrain the vertical component of the fault displacement, which seems to be the predominant component in any case.

In the northern sector, the Pliocene-Holocene SSTBs are also thicker than anywhere else. They reach a maximum value of $700 \mathrm{~m}$, and then become progressively shallower toward the south where the AFS at depth is less developed, i.e., where there are fewer deep-seated fault segments and the zone affected by brittle features is narrower. The marked highs and lows of the thickness values (Figure 8C), as reported in the northern sector, could have been influenced by the lower density of the data (more loosely spaced seismic lines). There, the correlation of different line drawings across the seismic profiles is more difficult, and the presence of sporadic diapirism also influence the deformation at the seafloor (Polonia et al., 2017a). Nonetheless, the observed general trend of southeastward decreasing sediment thickness should not have been affected by this limitation.

If we assume, as suggested by the geometric correspondence illustrated above, that the formation and thickness of SSTBs and the activity of the AFS segments at depth are correlated, we can then interpret the average decreasing sediment thickness of the SSTBs as being related to the progressively younger age of the AFS segments toward the front of the accretionary wedge. This interpretation is supported by considering that the pelagic sedimentation rates, found at the front of the Calabrian accretionary wedge by radiocarbon dating of core logs (Polonia et al., 2013, 2017a), are the same as the average sedimentation rates measured in the northern sector (Figure 5, Section A, and Figure 9).
Applying the same approach for the determination of the age of fault inception described above to the configuration of the SSTB in the southeastern area (Figure 5, Section E) we obtain an age of 1.3 Ma for the formation of the SSTB in this location. Then, observing in parallel the configurations shown in Section E and Section F (Figure 5) we argue that the accommodation space that hosts the SSTBs should precede the formation of the offset at depth across the subduction interface, and the nucleation of the shallow faults. In facts, the basin in Section F is already partially developed although no shallow fault controls it yet, while the bending at depth is already well developed. Considering these age constraints, the AFS deep-seated segments should have appeared in the northern sector at about 2.6 Ma and should have grown across the southern sector since then (Figure 10B). The AFS grew in length some $80 \mathrm{~km}$ (from Section A to Section E) in about $1.3 \mathrm{Myr}$, which results in a propagation rate of $62 \mathrm{~mm} / \mathrm{yr}$. At a later stage, its leading tip propagated southward only by less than $20 \mathrm{~km}$ (from Section E to ahead of Section F) in another stage of $1.3 \mathrm{Myr}$, which makes a propagation rate of $15 \mathrm{~mm} / \mathrm{yr}$ at maximum. With Section $\mathrm{F}$ in mind, the first manifestation in either development stage of the AFS should have been the bending of the lower plate that created the accommodation space to host the Pliocene-Holocene SSTBs. This interpretation is in agreement with the data presented by Gallais et al. (2013) which show that in their profile "Archimede 2," located $10 \mathrm{~km}$ to the south of Section F (Figure 5), also the bending of the lower plate is not observable because the area was not reached yet by the deformation due to the AFS propagation.

Using the age of inception of the AFS activity in the northern sector (2.6 Ma) as a proxy, the vertical component of the total slip rate is $2.31 \mathrm{~mm} / \mathrm{yr}$, i.e., $0.6 \mathrm{~mm} / \mathrm{yr}$ as an average value equally partitioned on each of the four segments. In the southern part, where only one major fault segment constitutes the AFS with a maximum throw of $1,300 \mathrm{~m}$ and the age of inception of such segment is younger $(1.3 \mathrm{Ma})$, the vertical component of the slip rate is in the order of about $1 \mathrm{~mm} / \mathrm{yr}$.

Therefore, putting together the following considerations: (1) the inception age of the AFS in the northern sector is c. $2.6 \mathrm{Ma}$, (2) the accretionary wedge must have already been structured at that time in that sector, and (3) the toe of the accretionary wedge presently lays c. $85 \mathrm{~km}$ to the southeast of the leading tip of the AFS, we deduce that the formation of the accretionary wedge (and thus the propagation of the subduction interface) precedes the inception of the activity of the AFS (Figure 10B).

\section{Tectonic Implications}

The migration of the Calabrian Arc subduction system have significantly slowed down over time (Wortel and Spakman, 2000; Goes et al., 2004; Rosenbaum and Lister, 2004; Faccenna, 2005; Mattei et al., 2007) and it is still weakly active (Palano et al., 2017). This characteristic of the subduction process provides a critical constraint for modeling the present day activity and potential earthquake production of the slab interface (Carafa et al., 2018; Nijholt et al., 2018). Both the propagation and displacement rates of the AFS also significantly slowed down over time, implying that the subduction process and AFS development are interdependent. In the northern sector, we may speculate that 
in the earlier times the rate could have even been faster than our average estimate because the fault propagation could have slowed down to get across the Alfeo Seamount. The N-S seismic profile (Figure 3) shows the role of the continental block of the Alfeo Seamount in halting the propagation of the accretionary wedge, which gets thicker against it and thinner south of it, and in driving the change of style of the AFS (Figure 5).

The northernmost seismic profile (Figure 5A) also shows the relationship between the AFS and the paleo-margin of the Malta Escarpment. The western part of the section shows a chaotic body, possibly related to one or two major mega-flood events (Micallef et al., 2018; Camerlenghi et al., 2019), which drapes the western lateral toe of the accretionary wedge. Note that, except for minor deformation related to salt tectonics at the toe of the accretionary wedge, there is no evidence of active tectonics recorded by the Pliocene-Holocene unit at the base of the Malta Escarpment, whose activity terminates in the Lower Cretaceous as documented by Tugend et al. (2019). All together, these observations contradict the interpretation of the Malta Escarpment as a major Quaternary fault like so far proposed (e.g., Monaco and Tortorici, 2000; among many others; Gerardi et al., 2008; Argnani et al., 2012). Our data show that primary evidence of syn-sedimentary Pliocene-Holocene tectonic activity is found only in the SSTBs located above the AFS and favors the interpretation of the major active tectonic boundary between the Calabrian subduction and the African plate to be located more toward the East, as already proposed by Gutscher et al. (2017) and Dellong et al. (2018). Although our interpretation agrees with that of Dellong et al. (2018) in many aspects, we must highlight a few essential differences. The AFS movement at depth is mainly normal, eastern side down, not transcurrent; the apparent lateral displacement only affects the CAW in conjunction with the AFS southward propagation; the main faults only affect the lower plate; the brittle deformation features that affect the upper plate are the manifestation of a secondary process (bendingmoment faults?).

Overall, the analysis of our dataset provided a comprehensive picture of the deep-seated segments of the AFS, confirming the role of this fault system as a lithospheric tear, i.e., the actual, and possibly active, southwestern subduction-tear edge propagator of the Calabrian Arc (Figure 10) since at least 2.6 Myr. In the southern sector and below the Calabrian accretionary wedge, the AFS is characterized by sub-vertical deep-seated faults cutting through the oceanic crust. In the northern sector, these faults could be related to the transition between oceanic and continental crust along the Africa paleo-margin, as already suggested by Polonia et al. (2017b) considering the distribution of Mesozoic serpentinites incorporated within the Calabrian accretionary wedge.

\section{CONCLUSION}

The tear faults forming the subducting slab lateral edges are an essential part of the subduction process. Such faults are widespread all over the globe, but their behavior is not exhaustively documented. Here, we focused on one such fault, namely the Alfeo Fault System (AFS), in the Calabrian Arc, Italy. Thanks to the high quality of the seismic imagery, coupled with independent literature data, we were able to explore several of its features in detail. We confirmed the role of the AFS as a lithospheric tear. The AFS evolves with a scissorlike mechanism, i.e., with a Mode III of fracture propagation, resulting from the bending of the oceanic crust driven by the slab-hinge migration. We could also determine that AFS is made up by four deep-seated major fault segments that clearly offset the subduction interface. Despite the significant dimension (we followed the AFS for over $180 \mathrm{~km}$ of length in the Ionian offshore) and maximum cumulative displacement (exceeding $6,000 \mathrm{~m}$ ), the deep-seated fault segments are decoupled from the shallow faults that were well-mapped at the seafloor in previous works. Because of decoupling, the AFS deep-seated segments cannot propagate upward across the accretionary wedge, nonetheless, their bending moment deforms the uppermost stratigraphic layers driving the development of shallow syn-tectonic basins sitting right above them. Considering the uneven displacement distribution along the strike of major fault segments and the age of the shallow basin infill, which in turn constrain the age of fault inception, we observed that the propagation rate and the slip rate of the tear have significantly slowed down over time (during the last 2.6 Myr) and toward the southernmost fault tip right ahead of the subduction front. Since the formation of the accretionary wedge precedes the development of the AFS, we also speculate that the already documented slowing down of the Calabrian Arc migration could be the mechanism which drives the AFS waning over recent times.

\section{DATA AVAILABILITY STATEMENT}

The data analyzed in this study was obtained from TGS, under a non-exclusive confidentiality agreement, and from CNR-ISMAR under the payment of a fee. Requests to access these datasets should be directed to TGS https://www.tgs.com/ and to CNRISMAR http://www.crop.cnr.it/, respectively.

\section{AUTHOR CONTRIBUTIONS}

FM contributed to the data analysis and interpretation of the results, review of the literature data, and preparation of the figures. MT contributed to the review of the literature data and the interpretation of the results. $\mathrm{RB}$ contributed to the work planning and the interpretation of the results. All authors contributed to the preparation of the manuscript.

\section{FUNDING}

This work received financial support from the TSUMAPSNEAM Project, co-financed by the European Union Civil Protection Mechanism, Agreement Number: ECHO/SUB/2015/718568/PREV26; and the INGV Centro per la Pericolosità Sismica (CPS, Seismic Hazard Centre). 


\section{ACKNOWLEDGMENTS}

We acknowledge the following sources of the data used in this work: TGS for providing the CA99 and MEM07 seismic profiles under the confidentiality agreement CA-60 with INGV; R. Nicolich for making available the Etnaseis seismic profiles; CNR-ISMAR for supplementary information about the CROP seismic profile. We also acknowledge IHS Markit Ltd. for providing the educational license of the Kingdom Suite Software, dGB Earth Sciences for providing the OpendTect software under the General Public License. The bathymetric

\section{REFERENCES}

Argnani, A., Armigliato, A., Pagnoni, G., Zaniboni, F., Tinti, S., and Bonazzi, C. (2012). Active tectonics along the submarine slope of south-eastern Sicily and the source of the 11 January 1693 earthquake and tsunami. Nat. Hazard. Earth Syst. Sci. 12, 1311-1319. doi: 10.5194/nhess-12-1311-2012

Barreca, G., Scarfi, L., Cannavò, F., Koulakov, I., and Monaco, C. (2016). New structural and seismological evidence and interpretation of a lithospheric-scale shear zone at the southern edge of the Ionian subduction system (centraleastern Sicily, Italy). Tectonics 35, 1489-1505. doi: 10.1002/2015tc004057

Barreca, G., Scarfi, L., Gross, F., Monaco, C., and De Guidi, G. (2019). Fault pattern and seismotectonic potential at the south-western edge of the Ionian Subduction system (southern Italy): new field and geophysical constraints. Tectonophysics 761, 31-45. doi: 10.1016/j.tecto.2019.04.020

Basili, R., Tiberti, M. M., Kastelic, V., Romano, F., Piatanesi, A., Selva, J., et al. (2013). Integrating geologic fault data into tsunami hazard studies. Nat. Hazards Earth Syst. Sci. 13, 1025-1050. doi: 10.5194/nhess-13-1025-2013

Bilich, A., Frohlich, C., and Mann, P. (2001). Global seismicity characteristics of subduction-to-strike-slip transitions. J. Geophys. Res. Solid Earth 106, 1944319452. doi: 10.1029/2000jb900309

Bonini, L., Basili, R., Toscani, G., Burrato, P., Seno, S., and Valensise, G. (2015). The role of pre-existing discontinuities in the development of extensional faults: an analog modeling perspective. J. Struct. Geol. 74, 145-158. doi: 10.1016/j.jsg. 2015.03.004

Bonini, L., Basili, R., Toscani, G., Burrato, P., Seno, S., and Valensise, G. (2016). The effects of pre-existing discontinuities on the surface expression of normal faults: insights from wet-clay analog modeling. Tectonophysics 684, 157-175. doi: 10.1016/j.tecto.2015.12.015

Camerlenghi, A., Del Ben, A., Hübscher, C., Forlin, E., Geletti, R., Brancatelli, G., et al. (2019). Seismic markers of the Messinian salinity crisis in the deep Ionian Basin. Basin Res. 1-23. doi: 10.1111/bre.12392

Carafa, M. M. C., Barba, S., and Bird, P. (2015). Neotectonics and long-term seismicity in Europe and the Mediterranean region. J. Geophys. Res. Solid Earth 120, 5311-5342. doi: 10.1002/2014jb011751

Carafa, M. M. C., Kastelic, V., Bird, P., Maesano, F. E., and Valensise, G. (2018). A "Geodetic Gap" in the calabrian arc: evidence for a locked subduction megathrust? Geophys. Res. Lett. 45, 1794-1804. doi: 10.1002/2017gl076554

Catalano, R., Doglioni, C., and Merlini, S. (2001). On the mesozoic Ionian Basin. Geophys. J. Int. 144, 49-64. doi: 10.1046/j.0956-540X.2000.01287.x

Chiarabba, C., and Palano, M. (2017). Progressive migration of slab break-off along the southern Tyrrhenian plate boundary: constraints for the present day kinematics. J. Geodyn. 105, 51-61. doi: 10.1016/j.jog.2017.01.006

Christophersen, A., Berryman, K., and Litchfield, N. (2015). The GEM Faulted Earth Project, Version 1.0.

Compagnoni, B., Galluzzo, F., Bonomo, R., Capotorti, F., D’Ambrogi, C., Di Stefano, R., et al. (2011). Carta Geologica d'Italia in scala 1:1.000.000. Firenze: ISPRA.

Cultrera, F., Barreca, G., Burrato, P., Ferranti, L., Monaco, C., Passaro, S., et al. (2017). Active faulting and continental slope instability in the Gulf of Patti (Tyrrhenian side of NE Sicily, Italy): a field, marine and seismological joint analysis. Nat. Hazards 86, 253-272. doi: 10.1007/s11069-016-2547-y

de Voogd, B., Truffert, C., Chamot-Rooke, N., Huchon, P., Lallemant, S., and Le Pichon, X. (1992). Two-ship deep seismic soundings in the basins of the metadata and Digital Terrain Model data products have been derived from the EMODnet Bathymetry portal - http://www. emodnet-bathymetry.eu. We thank the reviewers for their constructive comments.

\section{SUPPLEMENTARY MATERIAL}

The Supplementary Material for this article can be found online at: https://www.frontiersin.org/articles/10.3389/feart. 2020.00107/full\#supplementary-material

Eastern Mediterranean Sea (pasiphae cruise). Geophys. J. Int. 109, 536-552. doi: 10.1111/j.1365-246X.1992.tb00116.x

Del Ben, A., Barnaba, C., and Taboga, A. (2008). Strike-slip systems as the main tectonic features in the Plio-Quaternary kinematics of the Calabrian Arc. Mar. Geophys. Res. 29, 1-12. doi: 10.1007/s11001-007-9041-6

Dellong, D., Klingelhoefer, F., Kopp, H., Graindorge, D., Margheriti, L., Moretti, M., et al. (2018). Crustal structure of the Ionian basin and eastern Sicily margin: results from a wide-angle seismic survey. J. Geophys. Res. Solid Earth 123, 2090-2114. doi: 10.1002/2017jb015312

Devoti, R., Esposito, A., Pietrantonio, G., Pisani, A. R., and Riguzzi, F. (2011). Evidence of large scale deformation patterns from GPS data in the Italian subduction boundary. Earth Planet. Sci. Lett. 311, 230-241. doi: 10.1016/j.epsl. 2011.09.034

Devoti, R., Riguzzi, F., Cuffaro, M., and Doglioni, C. (2008). New GPS constraints on the kinematics of the Apennines subduction. Earth Planet. Sci. Lett. 273, 163-174. doi: 10.1016/j.epsl.2008.06.031

Faccenna, C. (2005). Constraints on mantle circulation around the deforming Calabrian slab. Geophys. Res. Lett. 32:L06311. doi: 10.1029/2004gl021874

Finetti, I., and Morelli, C. (1972). Wide scale digital seismic exploration of the Mediterranean Sea. Boll. Geofis. Teor. Appl. 14, 291-342.

Gallais, F., Graindorge, D., Gutscher, M.-A., and Klaeschen, D. (2013). Propagation of a lithospheric tear fault (STEP) through the western boundary of the Calabrian accretionary wedge offshore eastern Sicily (Southern Italy). Tectonophysics 602, 141-152. doi: 10.1016/j.tecto.2012.12.026

Gallais, F., Gutscher, M.-A., Graindorge, D., Chamot-Rooke, N., and Klaeschen, D. (2011). A Miocene tectonic inversion in the Ionian Sea (central Mediterranean): evidence from multichannel seismic data. J. Geophys. Res. 116:B12108. doi: $10.1029 / 2011$ jb008505

Gallais, F., Gutscher, M.-A., Klaeschen, D., and Graindorge, D. (2012). Twostage growth of the Calabrian accretionary wedge in the Ionian Sea (Central Mediterranean): constraints from depth-migrated multichannel seismic data. Mar. Geol. 326-328, 28-45. doi: 10.1016/j.margeo.2012.08.006

Gerardi, F., Barbano, M. S., De Martini, P. M., and Pantosti, D. (2008). Discrimination of Tsunami sources (Earthquake versus Landslide) on the basis of historical data in eastern sicily and Southern Calabria. Bull. Seismol. Soc. Am. 98, 2795-2805. doi: 10.1785/0120070192

Goes, S., Giardini, D., Jenny, S., Hollenstein, C., Kahle, H. G., and Geiger, A. (2004). A recent tectonic reorganization in the south-central Mediterranean. Earth Planet. Sci. Lett. 226, 335-345. doi: 10.1016/j.epsl.2004. 07.038

Govers, R., and Wortel, M. J. R. (2005). Lithosphere tearing at STEP faults: response to edges of subduction zones. Earth Planet. Sci. Lett. 236, 505-523. doi: 10.1016/ j.epsl.2005.03.022

Grad, M., Tiira, T., and Esc Working Group. (2009). The Moho depth map of the European Plate. Geophys. J. Int. 176, 279-292. doi: 10.1111/j.1365-246X.2008. 03919.x

Guarnieri, P. (2006). Plio-Quaternary segmentation of the south Tyrrhenian forearc basin. Int. J. Earth Sci. 95, 107-118. doi: 10.1007/s00531-005-0005-2

Gutscher, M.-A., Dellong, D., Dominguez, S., Malavieille, J., Graindorge, D., and Klingelhoefer, F. (2019). Strike-slip faulting in the calabrian accretionary wedge: using analog modeling to test the kinematic boundary conditions of geodynamic models. Transf. Plate Bound. Fract. Zones 2019, 321-337. doi: 10.1016/b978-0-12-812064-4.00013-x 
Gutscher, M.-A., Dominguez, S., de Lepinay, B. M., Pinheiro, L., Gallais, F., Babonneau, N., et al. (2016). Tectonic expression of an active slab tear from high-resolution seismic and bathymetric data offshore Sicily (Ionian Sea). Tectonics 35, 39-54. doi: 10.1002/2015tc003898

Gutscher, M.-A., Kopp, H., Krastel, S., Bohrmann, G., Garlan, T., Zaragosi, S., et al. (2017). Active tectonics of the Calabrian subduction revealed by new multibeam bathymetric data and high-resolution seismic profiles in the Ionian Sea (Central Mediterranean). Earth Planet. Sci. Lett. 461, 61-72. doi: 10.1016/j.epsl. 2016.12.020

Hall, J., Aksu, A. E., Elitez, I., Yaltırak, C., and Çifçi, G. (2014). The FethiyeBurdur Fault Zone: a component of upper plate extension of the subduction transform edge propagator fault linking Hellenic and Cyprus Arcs, Eastern Mediterranean. Tectonophysics 635, 80-99. doi: 10.1016/j.tecto.2014.05.002

Hayes, G. P., Moore, G. L., Portner, D. E., Hearne, M., Flamme, H., Furtney, M., et al. (2018). Slab2, a comprehensive subduction zone geometry model. Science 362, 58-61. doi: 10.1126/science.aat 4723

ISIDe Working Group (2016). version 1.0.

Knott, S. D., and Turco, E. (1991). Late cenozoic kinematics of the Calabrian Arc, southern Italy. Tectonics 10, 1164-1172. doi: 10.1029/91TC01535

Maesano, F. E., and D'Ambrogi, C. (2017). Vel-IO 3D: a tool for 3D velocity model construction, optimization and time-depth conversion in $3 \mathrm{D}$ geological modeling workflow. Comput. Geosci. 99, 171-182. doi: 10.1016/j.cageo.2016. 11.013

Maesano, F. E., Tiberti, M. M., and Basili, R. (2017). The Calabrian Arc: threedimensional modelling of the subduction interface. Sci. Rep. 7:8887. doi: 10 . 1038/s41598-017-09074-8

Marsden, D. (1992). V 0-K method of depth conversion. Lead. Edge 11, 53-54. doi: $10.1190 / 1.1436898$

Mattei, M., Cifelli, F., and D'Agostino, N. (2007). The evolution of the Calabrian Arc: evidence from paleomagnetic and GPS observations. Earth Planet. Sci. Lett. 263, 259-274. doi: 10.1016/j.epsl.2007.08.034

Micallef, A., Camerlenghi, A., Garcia-Castellanos, D., Cunarro Otero, D., Gutscher, M. A., Barreca, G., et al. (2018). Evidence of the Zanclean megaflood in the eastern Mediterranean basin. Sci. Rep. 8:1078. doi: 10.1038/s41598-01819446-3

Milia, A., Iannace, P., Tesauro, M., and Torrente, M. M. (2017). Upper plate deformation as marker for the Northern STEP fault of the Ionian slab (Tyrrhenian Sea, central Mediterranean). Tectonophysics 710-711, 127-148. doi: 10.1016/j.tecto.2016.08.017

Minelli, L., and Faccenna, C. (2010). Evolution of the Calabrian accretionary wedge (central Mediterranean). Tectonics 29:TC4004. doi: 10.1029/2009tc002562

Monaco, C., and Tortorici, L. (2000). Active faulting in the Calabrian arc and eastern Sicily. J. Geodyn. 29, 407-424. doi: 10.1016/S0264-3707(99)00052-6

Müller, R. D., Sdrolias, M., Gaina, C., and Roest, W. R. (2008). Age, spreading rates, and spreading asymmetry of the world's ocean crust. Geochem. Geophys. Geosyst. 9:Q04006. doi: 10.1029/2007gc001743

Nicolich, R., Laigle, M., Hirn, A., Cernobori, L., and Gallart, J. (2000). Crustal structure of the Ionian margin of Sicily: etna volcano in the frame of regional evolution. Tectonophysics 329, 121-139. doi: 10.1016/s0040-1951(00)00192-x

Nijholt, N., Govers, R., and Wortel, R. (2018). On the forces that drive and resist deformation of the south-central Mediterranean: a mechanical model study. Geophys. J. Int. 214, 876-894. doi: 10.1093/gji/ggy144

Orecchio, B., Presti, D., Totaro, C., D’Amico, S., and Neri, G. (2015). Investigating slab edge kinematics through seismological data: the northern boundary of the Ionian subduction system (south Italy). J. Geodyn. 88, 23-35. doi: 10.1016/j.jog. 2015.04.003

Orecchio, B., Presti, D., Totaro, C., and Neri, G. (2014). What earthquakes say concerning residual subduction and STEP dynamics in the Calabrian Arc region, south Italy. Geophys. J. Int. 199, 1929-1942. doi: 10.1093/gji/ggu373

Özbakır, A. D., Şengör, A. M. C., Wortel, M. J. R., and Govers, R. (2013). The Pliny-Strabo trench region: a large shear zone resulting from slab tearing. Earth Planet. Sci. Lett. 375, 188-195. doi: 10.1016/j.epsl.2013. 05.025

Palano, M., Piromallo, C., and Chiarabba, C. (2017). Surface imprint of toroidal flow at retreating slab edges: the first geodetic evidence in the Calabrian subduction system. Geophys. Res. Lett. 44, 845-853. doi: 10.1002/2016g1071452

Polonia, A., Nelson, C. H., Romano, S., Vaiani, S. C., Colizza, E., Gasparotto, G., et al. (2017a). A depositional model for seismo-turbidites in confined basins based on Ionian Sea deposits. Mar. Geol. 384, 177-198. doi: 10.1016/j.margeo. 2016.05.010
Polonia, A., Panieri, G., Gasperini, L., Gasparotto, G., Bellucci, L. G., and Torelli, L. (2013). Turbidite paleoseismology in the calabrian arc subduction complex (Ionian Sea). Geochem. Geophys. Geosyst. 14, 112-140. doi: 10.1029/ $2012 \mathrm{gc004402}$

Polonia, A., Torelli, L., Artoni, A., Carlini, M., Faccenna, C., Ferranti, L., et al. (2016). The ionian and alfeo-Etna fault zones: new segments of an evolving plate boundary in the central Mediterranean Sea? Tectonophysics 675, 69-90. doi: 10.1016/j.tecto.2016.03.016

Polonia, A., Torelli, L., Gasperini, L., Cocchi, L., Muccini, F., Bonatti, E., et al. (2017b). Lower plate serpentinite diapirism in the Calabrian Arc subduction complex. Nat. Commun. 8:2172. doi: 10.1038/s41467-017-02273-x

Polonia, A., Torelli, L., Mussoni, P., Gasperini, L., Artoni, A., and Klaeschen, D. (2011). The Calabrian Arc subduction complex in the Ionian Sea: regional architecture, active deformation, and seismic hazard. Tectonics 30:TC5018. doi: $10.1029 / 2010$ tc002821

Rosenbaum, G., and Lister, G. S. (2004). Neogene and quaternary rollback evolution of the Tyrrhenian Sea, the Apennines, and the Sicilian Maghrebides. Tectonics 23:TC1013. doi: 10.1029/2003tc001518

Rovida, A., Locati, M., Camassi, R., Lolli, B., and Gasperini, P. (2019). Catalogo Parametrico dei Terremoti Italiani (CPTI15), versione 2.0.

Royden, L., Patacca, E., and Scandone, P. (1987). Segmentation and configuration of subducted lithosphere in Italy: an important control on thrust-belt and foredeep-basin evolution. Geology 15, 714-717. doi: 10.1130/0091$7613198715<714:$ SACOSL $<2.0$. CO $; 2$

Sachpazi, M., Hirn, A., Clément, C., Haslinger, F., Laigle, M., Kissling, E., et al. (2000). Western Hellenic subduction and Cephalonia Transform: local earthquakes and plate transport and strain. Tectonophysics 319, 301-319. doi: 10.1016/S0040-1951(99)00300-5

Scordilis, E. M., Karakaisis, G. F., Karacostas, B. G., Panagiotopoulos, D. G., Comninakis, P. E., and Papazachos, B. C. (1985). Evidence for transform faulting in the Ionian sea: the Cephalonia island earthquake sequence of 1983. Pure Appl. Geophys. 123, 388-397. doi: 10.1007/bf00880738

Stampfli, G. M., and Borel, G. D. (2002). A plate tectonic model for the Paleozoic and Mesozoic constrained by dynamic plate boundaries and restored synthetic oceanic isochrons. Earth Planet. Sci. Lett. 196, 17-33. doi: 10.1016/S0012821X(01)00588-X

Tiberti, M. M., Vannoli, P., Fracassi, U., Burrato, P., Kastelic, V., and Valensise, G. (2017). Understanding seismogenic processes in the southern Calabrian Arc: a geodynamic perspective. Ital. J. Geosci. 136, 365-388. doi: 10.3301/IJG.2016.12

Tugend, J., Chamot-Rooke, N., Arsenikos, S., Blanpied, C., and Frizon de Lamotte, D. (2019). Geology of the ionian basin and margins: a key to the East Mediterranean geodynamics. Tectonics 28, 2668-2702. doi: 10.1029/ $2018 \mathrm{tc} 005472$

van Hinsbergen, D. J. J., Vissers, R. L. M., and Spakman, W. (2014). Origin and consequences of western Mediterranean subduction, rollback, and slab segmentation. Tectonics 33, 393-419. doi: 10.1002/tect.20125

Vasquez, L., Nalpas, T., Ballard, J.-F., Le Carlier De Veslud, C., Simon, B., Dauteuil, O., et al. (2018). 3D geometries of normal faults in a brittle-ductile sedimentary cover: analogue modelling. J. Struct. Geol. 112, 29-38. doi: 10.1016/j.jsg.2018. 04.009

Wdowinski, S., Ben-Avraham, Z., Arvidsson, R., and Ekström, G. (2006). Seismotectonics of the Cyprian Arc. Geophys. J. Int. 164, 176-181. doi: 10.1111/ j.1365-246X.2005.02737.x

Withjack, M. O., and Callaway, S. (2000). Active normal faulting beneath a salt layer: an experimental study of deformation patterns in the cover sequence. AAPG Bull. 84, 627-651.

Wortel, M. J. R., and Spakman, W. (2000). Subduction and slab detachment in the Mediterranean-Carpathian region. Science 290, 1910-1917. doi: 10.1126/ science.290.5498.1910

Conflict of Interest: The authors declare that the research was conducted in the absence of any commercial or financial relationships that could be construed as a potential conflict of interest.

Copyright (c) 2020 Maesano, Tiberti and Basili. This is an open-access article distributed under the terms of the Creative Commons Attribution License (CC BY). The use, distribution or reproduction in other forums is permitted, provided the original author(s) and the copyright owner(s) are credited and that the original publication in this journal is cited, in accordance with accepted academic practice. No use, distribution or reproduction is permitted which does not comply with these terms. 